\title{
Synthesis, Characterization and Anticancer Evaluation of Nitrogen Substituted 1-(3-Aminoprop- 1-ynyl)-4-Hydroxyanthraquinone Derivatives
}

\section{Nafisa S. Sirazhetdinova}

Vorozhtsov Novosibirsk Institute of Organic Chemistry SB RAS: Novosibirskij institut organiceskoj himii imeni N N Vorozcova SO RAN

\section{Dmitry S Baev}

Vorozhtsov Novosibirsk Institute of Organic Chemistry SB RAS: Novosibirskij institut organiceskoj himii imeni N N Vorozcova SO RAN

\section{Victor A. Savelyev}

Vorozhtsov Novosibirsk Institute of Organic Chemistry SB RAS: Novosibirskij institut organiceskoj himii imeni N N Vorozcova SO RAN

\section{Tatyana S. Golubeva}

Vorozhtsov Novosibirsk Institute of Organic Chemistry SB RAS: Novosibirskij institut organiceskoj himii imeni N N Vorozcova SO RAN

Lyubov S. Klimenko

Yugra State University

\section{Tatyana G. Tolstikova}

Vorozhtsov Novosibirsk Institute of Organic Chemistry SB RAS: Novosibirskij institut organiceskoj himii imeni N N Vorozcova SO RAN

\section{Jamsranjav Ganbaatar}

Institute of chemistry and chemical technology

Elvira EShults ( $\sim$ schultz@nioch.nsc.ru )

Novosibirskij institut organiceskoj himii imeni N N Vorozcova SO RAN https://orcid.org/0000-00020761-9696

\section{Research Article}

Keywords: Anthraquinone, Sonogashira reaction, A3-Coupling, Anti-cancer, DNA, G-quadruplex

Posted Date: March 18th, 2021

DOl: https://doi.org/10.21203/rs.3.rs-306809/v1 
License: (c) (i) This work is licensed under a Creative Commons Attribution 4.0 International License. Read Full License 


\section{Abstract}

Anthraquinones are of significant interest due to their biological activity, coloring properties and synthetic applications. Here, we describe a mild and convenient method for modification of 1-ethynyl-4hydroxyanthraquinone that was obtained from the Sonogashira reaction of 1-hydroxy-4iodoanthraquinone with alkynes. The copper(I) catalyzed one-pot three component reaction ( $\mathrm{A}^{3}$-coupling) of the new 1-ethynyl-4-hydroxyanthraquinone with secondary amines and formaldehyde was the main approach for the synthesis of nitrogen substituted 1-[3-(amino)prop-1-ynyl]-4-hydroxyanthraquinones. The influence of different substituent in the amine on reaction rate and yield has been evaluated. The cytotoxicity of 1-ethynyl-4-hydroxyanthraquinones was evaluated using the conventional MTT assay. Among all the compounds synthesized, anthraquinone-propargylamine derivatives 28, 29, 30 and 34 possess most promising cytotoxic potential towards glioblastoma cancer cells; compounds 14 and 19 shown selectivity towards the prostate cancer cells DU-145, and 18, and 24 - towards breast cancer cells MCF-7. The grown inhibition on these cancer cells of 18 and 24 was comparable to those of standard drug Doxorubicin. Molecular modeling of new compounds in DNA G-quadruplex binding site was performed to help understand the observed SAR trends.

\section{Introduction}

The derivatives of anthracene-9,10-dione (anthraquinone) were of interest in many applications, in particular, are well known for their diverse and profound biological activities [1]. They are effective to treat tumors and cancers [2-4], and also used as antibacterial [5, 6], antifungal, insecticidal [7], antimicrobial $[8,9]$, and as antidiabetic [10] agents. Antraquinones were widely studied for their structural evaluation and biological significance. Antracenedione drugs are known to exert their biological effects through interaction with DNA resulting in modification of its structure hence inhibition of its replication. Anthraquinones mitoxantrone and ametantrone (1,4-bis[(aminoalkyl)amino]antracene-9,10-diones) are potent synthetic anticancer drugs which blocs DNA synthesis by inhibiting the function of DNA topoisomerases $[11,12]$. Several anthraquinone pharmacophores can realize theirs anticancer activity by affecting other molecular targets. For example, a new rhein-derived compound can target MDM2 for protein degradation by binding to MDM2 and blocking the interaction between MDM2 and MDM4 which leads to MDM2 self-ubiquitination and degradation; this in turn causes p53 activation and cancer cell apoptosis, particularly in cancer cells expressing high levels of MDM2 [13]. Purpurin (1,2,4-trihydroxy-9,10anthraquinone) is a non-competitive inhibitor of adipocyte-derived leucine aminopeptidase (A-LAP) which play a crucial role in angiogenesis [14]. Emodin (1,3,8-trihydroxy-6-methylanthraquinone) was characterized as an significant inhibitor of cell proliferation, presumably via down regulation of ERCC1 (excision repair cross-complementary 1) and DNA recombinase protein Rad51 [15], but its 2,4-dibromo derivatives exert their anti-proliferative activity at least in part, by inhibition of ATP citrate lyase (ACL), plays a critical role in generating cytosolic acetyl CoA [16]. Emodin and 2-chloroemodin were also considered as potential targets of dioxygenases (ALKBH 2, 3 proteins, and FTO) overexpression blockers [17]. Purpurin [18] and emodin [19] were also characterized as monoamine oxidase isoforms inhibitors. 
A series of studies have been focused on optimization of efficacy and safety profile of anthraquinonebased compounds [20]. Of particular interest in the search of antitumor agents is the development of studies on the preparation of anthraquinone derivatives containing nitrogen substituents, including piperidine [21] and pyrimidine [22] fragments.

For synthesis of nitrogen substituted anthraquinones, besides to the routes for the construction of anthraquinone core (for example, of Friedel-Crafts condensations of benzene derivatives with functionalized phthalic anhydrides or phthaloyl dichlorides [23]), attention has been drawn to the development of $\mathrm{C}-\mathrm{N}$ coupling processes, for example, the copper(0)-catalyzed Ullmann-type reaction of bromo/chloro anthraquinones with a variety of amines [24-27] or the Pd-catalyzed Buchwald-Hartwig cross-coupling reaction of halogen substituted anthraquinones [28, 29].

In the framework of our studies dealing with the development of convenient routes to functionalization of 1-hydroxyanthraquinone [30], we were interested in the preparation of anthraquinone derivatives, containing an aminopropargyl substituent in the anthraquinone core. Propargylamines are a versatile class of compounds whose application in medicinal and pharmaceutical chemistry has really soared [31]. The copper $(I)$ catalyzed one-pot three component ( $A^{3}$-coupling) reaction among aldehyde, amine and terminal alkyne has become a popular approach to synthesize propargylamines [32,33]. Therefore, the sequence of the Sonogashira cross-coupling reaction of 4-iodo-1-hydroxyanthraquinone with alkynes and the copper catalyzed Mannich reaction of 1-ethynyl-4-hydroxyanthraquinone with secondary amines and formaldehyde (37\% Eq. solution or paraform) ( $\mathrm{A}^{3}$-coupling) was used as the main synthetic approach in this studies. Taken into account the interest to substituted anthraquinones as anticancer agents we evaluated the cytotoxicity of the synthesized compounds toward cancer cell lines in vitro. The molecular docking of new compounds to G-quadruplex DNA motifs was carried out.

\section{Results And Discussion}

\subsection{Chemical Synthesis}

The cross-coupling reaction of 1-hydroxy-4-iodo-9,10-anthraquinone 1 [34] with phenylacetylene 2 was used as the model reaction to optimize the conditions (Scheme 1). The reaction of $\mathbf{1}$ and $\mathbf{4}$ in standard Sonogashira reaction conditions [35] in the presence of dichlorobis(triphenylphosphine)]palladium, copper(I) iodide, and triethylamine as a base in benzene or toluene under reflux was unsuccessful. Carrying out the reaction in DMF at $100-120^{\circ} \mathrm{C}$ and using of an excess of triethylamine was found to be ineffective. An efficient way to improve the yield of the cross-coupling reaction products was the addition of tetraalkylammonium salts to the reaction mixture as proposed by Jeffery [36]. The ability to generate a stable form of the catalyst without the addition of stabilizing ligands as one of the role of tetraalkylammonium salts was reported by Reetz [37]. The cross-coupling reaction of 1-hydroxy-4-iodo9,10-anthraquinone $\mathbf{1}$ with phenylacetylene $\mathbf{4}$ in the presence of dichlorobis(triphenylphosphine)]palladium, copper(I) iodide, triethylamine (3 equiv.) and ammonium salts 
$\left(\mathrm{Bu}_{4} \mathrm{NBr}\right)$ (1 equiv.) in DMF by heating at $65^{\circ} \mathrm{C}$ for $1 \mathrm{~h}$ (TLC) afforded the 4-phenyl-1-

hydroxyanthraquinone 3 in $78 \%$ yield. We got a similar result when using 0.2 equiv. of $\mathrm{Bu}_{4} \mathrm{NBr}$; the isolated yield of compound $\mathbf{3}$ composed to $82 \%$. In this condition, the reaction of 1-hydroxy-4-iodo-9,10anthraquinone 1 with 4-methoxyphenylacetylene 4, 4-fluorophenylacetylene 5, or 4-acetylamino-3ethoxycarbonylphenylacetylene 6 led to the corresponding 4-aryl-1-hydroxyanthraquinones 7-9 in the isolated yield $52,46,41 \%$ respectivelly.

The reaction of iodoanthraquinone 1 with trimethylsilylacetylene 10 in the found condition proceeded more smoothly afforded the coupling compound $\mathbf{1 1}$ in the yield 83\%. Desilylation by the action of tetrabutylammonium fluoride in methylene chloride afforded the corresponding terminal acetylene 12. Thus, we proposed a simple and convenient three step procedure for the synthesis of 1-ethynyl-4hydroxyanthracene-9,10-dione 12 with the yield about $49 \%$ from 1-hydroxyanthraquinone.

For the synthesis of $\mathrm{N}$-substituted 1-(3-aminopropargyl)-4-hydroxyanthraquinones we studied the the $\mathrm{Cu}(\mathrm{I})$ iodide-catalyzed A3 coupling reaction between 1-ethynyl-4-hydroxyanthracene-9,10-dione 12, formaldehyde and different secondary amines. We found that the reaction of compound $\mathbf{1 2}$, formaldehyde (generated in situ from paraformaldehyde) and diethylamine 13 in dioxane in the presence of 0.02 equiv of copper(I) iodide at $65^{\circ} \mathrm{C}$ procceds smoothly, and after 30 min the alkyne was almost consumed and the desired N-(dimethyl)- substituted 1-(3-aminopropargyl)-4-hydroxyanthraquinone 14 was isolated in the yield $50 \%$ (Scheme 2). Copper(I) chloride was less effective with increasing the reaction time to $1.5 \mathrm{~h}$ and yield decreasing to $39 \%$. Performing the reaction in the presence of copper (II) acetate monohydrate in dioxane led to a slightly improved the yield to $57 \%$. By using of $\mathrm{Cu}(\mathrm{OAc})_{2} \times \mathrm{H}_{2} \mathrm{O}$ as the catalyst and aqueous formaldehyde as the reagent the yield of compound $\mathbf{1 4}$ increased to $73 \%$. In this conditions 1-hydroxy-4-ethynylanthraquinone 1 was reacted with acyclic secondary amines 15-17 $\left(65^{\circ} \mathrm{C}, 1-2 \mathrm{~h}\right)$ to give desired compounds $18-20$ with high yield (Scheme 2). Reaction of cyclic secondary amines pyrrolidines $\mathbf{2 1}, \mathbf{2 2}$, piperidines $\mathbf{2 5 - 2 7}$, morpholine $\mathbf{3 1}, \mathrm{N}$-methylpiperazine $\mathbf{3 2}$, and azocane 35 with aqueous formaldehyde and alkynylanthraquinone 1 in the presence of $\mathrm{Cu}(\mathrm{OAc})_{2} \times \mathrm{H}_{2} \mathrm{O}$ required longer time and afforded aminopropargyl substituted anthraquinones 23, 24, 28-30, 33, 34 and 36 in high yield. All the derivatives were purified by column chromatography (chloroform:ethylacetate, solvent mixture). After the purity controls of the synthesized compounds (TLC studies) and their melting points were determined, spectral analyzes were performed to prove the structures. ${ }^{1} \mathrm{H}-\mathrm{NMR},{ }^{13} \mathrm{C} \mathrm{NMR}$, and mass spectral analysis were found to prove the expected structures.

It is well known, that the reported reaction is thought to proceed through the alkyne activation forming a copper acetylide. After a nucleophilic addition on the intermediate formed by the reaction of formaldehyde and a secondary amine, the propargylamine derivative is obtained [32]. We performed also a 'one-pot' deprotection $-A^{3}$-coupling tandem procedure for obtaining compound. Successful versions of the copper(I)-catalyzed reaction of azides with trimethylsilylalkynes in the presence of an organic base we reported [38,39]. We found, that a simple mixing of 12 , formalin, and amine 13 in the presence of

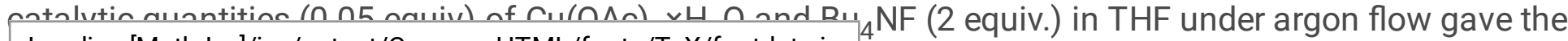
Loading [MathJax]/jax/output/CommonHTML/fonts/TeX/fontdata.js 
desired product 14 isolated in the yield $23 \%$. No products of alkyne deprotection reaction (compound 12 or dimeric butadiyne) was observed in this conditions.

All the new compounds exhibited satisfactory spectral data correlating with their structures, IR spectrum of all final compounds $6-9,11,12,14,18-20,23,24,28-30,33,34,36$ showed $C \equiv C$ stretching vibration around $2100-2205 \mathrm{~cm}^{-1}$. The structure of the synthesized 1-(3-aminopropargyl)-4-

hydroxyanthraquinones was clearly confirmed by the results of the NMR study. In particular, the $1 \mathrm{H}$ NMR spectra of $14,18-20,23,28,29,33,34,36$ contain the resonance signals of the $\mathrm{CH}_{2}$ group represented as a singlet of two protons at the range of $3.63-3.81 \mathrm{ppm}$. For these protons in the spectra for compounds 24 and $\mathbf{3 0}$, having substituent at the a-position of the heterocyclic ring, the doublet $A B$ system centered at 3.72 and $3.92 \mathrm{ppm}(\mathrm{J}=17.6 \mathrm{~Hz})$ or 3.41 and $3.52 \mathrm{ppm}(\mathrm{J}=17.6 \mathrm{~Hz})$ was observed. The ESI mass spectrometric data of all the synthesized compounds showed peaks at relevant $[M+H]+m / z$ which complemented the IR and NMR spectra for the confirmation of expected structures of all the compounds

\section{Cytotoxicity Studies}

Four cancer cell lines, MCF-7 (breast cancer cells), DU-145 (prostate cancer cells), SNB-19, and U-87 MG (glioblastoma cells), and also a normal cell line of immortalized human fibroblasts were chosen for cytotoxicity evaluations. MTT assays were performed for quantitative evaluation of in vitro cytotoxicity [40]. Doxorubicin (DOX) is clinically used to treat cancer as drug in world and have a very wide antitumor spectrum. That we use them as positive control compounds. The cytotoxicity was determined by measuring the concentration inhibiting human tumor cell viability by $50 \%\left(\mathrm{GI}_{50}\right)$. The results are presented in Table 1. The SAR revealed that the substituent at C-1 position of 4-hydroxyanthraquinones have a great influence on the cytotoxicity. Compounds $6,7,8,9$ with arylethynyl substituent exhibited low or insignificant cytotoxicity with high $\mathrm{Gl}_{50}$ values on the cancer cell lines. Previously, we have reported that 4-hydroxyanthraquinones with 1-arylsubstituent have great anticancer potency [30]. Spacing the aromatic ring away from anthraquinone by an ethynyl group led to greatly decrease of the anticancer potency. In comparison, all the 1-(3-( $N$-substituted)aminoprop-1-ynyl)-4-hydroxyanthraquinones 14 , 18$20,23,24,28-30,33,34$, and 36 shown much more potent cytotoxicity with significantly lower $\mathrm{GI}_{50}$ values on most of the tumor cells. Thus, we demonstrate that 1-position 3-aminopropinyl modification of 4-hydroxyanthraquinone can significantly potentiate the anticancer activity. A remarkable increase in activity towards breast cancer cell line MCF-7 was observed for compounds $18,24,29,36$; the effect in this cell line was comparable to that of Doxorubicin. Among these derivatives compounds $\mathbf{1 8}$ (with a dipropylamino- substituent at C-3) and $\mathbf{3 6}$ (with a cyclic azocane substituent at C-3) shown the higher cytotoxicity also towards normal cell lines. Among all analogues, compounds 14 and 19 with diethylaminopropynyl or di-i-propylaminopropynyl substituent showed high potency against prostate cancer cell line DU-145 (Table 1). The $\mathrm{Gl}_{50}$ value for those derivatives approaches that of the positive control, doxorubicin. Compound 28, contain the cyclic 3-(piperidino), 29 with 3-(4-methyl)piperidino-, and 30 with 3-(2-anabasinyl)piperidino substituent in the propin-1-yl side chain possess selective cytotoxicity towards alioblastoma cancer cells SNB-19 and U-87MG. Relative to doxorubicin, these derivatives Loading [MathJax]/jax/output/CommonHTML/fonts/TeX/fontdata.js 
showed by at least 4-10 fold less toxicity against normal cell line. The synthesized 3(pyrrolidino)propynyl- $\mathbf{2 3}$ was less active than 3-(piperidino)propynyl- $\mathbf{2 8}$ anthraquinone towards cancer cell lines. The N-methyl-piperidinopropynyl-1-hydroxyanthraquinone $\mathbf{3 4}$ demonstrated higher cytotoxicity than the morpholinopropynyl-1-hydroxyanthraquinone $\mathbf{3} 3$ on cancer cells. All the obtained results suggested that the substituent at the nitrogen of 4-(aminopropargyl)-1-hydroxyanthraquinones increased the cytotoxicity. There have been previous studies on the anticancer properties of aminoanthraquinones with the aminoalkylamino side chains at the 1-1,4-1,5- or 1,8-positions [41-45]. These reports suggest that the substitution by $1-(\mathrm{N}, \mathrm{N}$-dimethylamino)ethylamine side chain led to optimal activity: compounds with 1-(N,N-dimethylamino)propylamine substituent shown two fold decrease of cytotoxicity on cancer cell lines [44]. The modification in the chain second amine function also changed the cytotoxicity; compounds with morpholino(propylenamino)- substituted anthraquinones were less potent that compounds with piperidino- or pyrrolidino(propylenamino)- substituted anthraquinones against leukemia P388 cells [42] and compound with piperidino- moiety were more active that the pyrrolidino- substituted one in the ovarian cancer cell lines [45]. Herein we demonstrate that 3-position amine modification of 1(3-aminopropargyl)-substituent can also significantly potentiate the anticancer activity of hydroxyanthraquinone. 
Table 1

Cytotoxicity of compounds $6-9,14,18-20,23,24,28-30,33,34,36$

\begin{tabular}{|c|c|c|c|c|c|}
\hline \multirow[t]{2}{*}{ Compound } & \multicolumn{5}{|c|}{ Growth inhibition of cells $\left(\left.G\right|_{50}, \mu \mathrm{M}\right){ }^{[a, b]}$} \\
\hline & MCF-7 & DU-145 & SNB-19 & U-87 MG & hTERT lung fibroblasts \\
\hline 6 & $>100$ & $>100$ & $78.09 \pm 9.14$ & $>100$ & $>100$ \\
\hline 7 & $74.16 \pm 9.14$ & $>100$ & $62.03 \pm 5.11$ & $54.55 \pm 6.08$ & $68.25 \pm 4.22$ \\
\hline 8 & $>100$ & $>100$ & $>100$ & $>100$ & $>100$ \\
\hline 9 & $>100$ & $>100$ & $>100$ & $>100$ & $>100$ \\
\hline 14 & $15.66 \pm 2.14$ & $6.55 \pm 0.77$ & $21.45 \pm 1.33$ & $17.74 \pm 0.84$ & $18.24 \pm 0.88$ \\
\hline 18 & $5.45 \pm 0.87$ & $8.06 \pm 0.45$ & $4.23 \pm 0.85$ & $9.24 \pm 0.64$ & $8.23 \pm 0.54$ \\
\hline 19 & $12.33 \pm 2.74$ & $6.16 \pm 0.67$ & $8.64 \pm 1.07$ & $9.66 \pm 1.02$ & $15.22 \pm 2.34$ \\
\hline 20 & $8.46 \pm 0.92$ & $12.98 \pm 1.41$ & $10.29 \pm 1.37$ & $22.39 \pm 1.17$ & $12.45 \pm 1.22$ \\
\hline 23 & $14.72 \pm 2.15$ & $13.64 \pm 1.09$ & $7.58 \pm 0.44$ & $17.06 \pm 1.44$ & $54.29 \pm 3.07$ \\
\hline 24 & $6.02 \pm 1.11$ & $9.48 \pm 1.55$ & $7.08 \pm 1.31$ & $8.15 \pm 0.72$ & $15.46 \pm 2.07$ \\
\hline 28 & $9.44 \pm 1.03$ & $8.33 \pm 0.71$ & $5.66 \pm 1.08$ & $6.05 \pm 0.76$ & $22.68 \pm 2.08$ \\
\hline 29 & $7.07 \pm 1.15$ & $10.44 \pm 1.03$ & $5.02 \pm 0.88$ & $8.29 \pm 1.42$ & $21.26 \pm 0.84$ \\
\hline 30 & $13.28 \pm 2.04$ & $47.19 \pm 9.08$ & $7.09 \pm 1.13$ & $6.33 \pm 0.96$ & $31.56 \pm 2.48$ \\
\hline 33 & $34.62 \pm 1.28$ & $50.29 \pm 2.15$ & $30.15 \pm 2.15$ & $43.85 \pm 2.45$ & $54.09 \pm 7.11$ \\
\hline 34 & $7.56 \pm 1.11$ & $14.16 \pm 1.41$ & $6.67 \pm 0.62$ & $15.77 \pm 1.38$ & $38.22 \pm 2.41$ \\
\hline 36 & $7.48 \pm 1.03$ & $7.48 \pm 1.44$ & $5.13 \pm 0.56$ & $12.63 \pm 1.37$ & $6.25 \pm 1.02$ \\
\hline $\mathrm{DOX}^{\mathrm{C}}$ & $5.11 \pm 0.54$ & $6.61 \pm 0.34$ & $7.62 \pm 0.69$ & $6.11 \pm 0.15$ & $3.18 \pm 0.21$ \\
\hline
\end{tabular}

[a] $\mathrm{GI}_{50}$ : concentration at which $50 \%$ growth inhibition of tumor cells is observed after $72 \mathrm{~h}$ incubation;

[b] The experimental results are given as the data average values obtained from three independently conducted experiments; ${ }^{[c]}$ Doxorubicin.

\section{Modeling the possible interaction of new anthraquinones with the G-quadruplex of DNA}

G-quadruplexes are widely represented in telomeric sequences, some promoter regions, as well as in the 5 -untranslated regions of mRNA. Stabilization of G-quadruplexes of telomeric sequences by small molecules promotes inhibition of telomerase, which exhibits increased activity in tumor cells. Binding of G-quadruplexes of oncogenic promoters leads to suppression of their expression. Thus, the interaction of molecules with the G-auadruplexes of DNA in tumor cells can trigger their apoptosis and develop a Loading [MathJax]/jax/output/CommonHTML/fonts/TeX/fontdata.js 
cytotoxic effect. G-quadruplex is currently investigated as a target for contrasting unregulated cell proliferation, neurodegeneration and viral replication [46]. Small molecules with a anthraquinone core [47] and hetaryl fused anthracene-9,10-diones [48] were able to interact with G-quadruplexes and capable of forming four-strand structures. Recently, the anthracene-9-propargylamine scaffold was characterized as a new G-quadruplex ligand [49].

G-quadruplex is a structure consisting of four nitrogenous guanine bases linked by eight hydrogen bonds. The $\pi$-systems of guanines are located in one plane, which creates the possibility of stacking interactions with planar condensed aromatic systems of small molecules. Naphthalene diimide compound MM41 stabilizes the G-quadruplex due to the interactions of its planar aromatic nucleus with the $\pi$-systems of the purine rings of all four guanines. The nitrogen atoms of the methylpiperazine and morpholine rings of branched substituents can be protonated, which makes it possible for the dynamic formation of hydrogen bonds with the oxygen atoms of phosphoric acid residues of neighboring nucleotides, depending on the position of the aromatic nucleus of the molecule above the plane of four guanines.

The results of docking studies of compounds $6,7,8,9,12,14,18,19,20,23,24,28,29,30,33,34$, 36, and MM41 in G-quadruplex binding site are listed in Table 2 and Fig. 1. Superposition of molecules over the plane of the G-quadruplex is given in Suppl. Part (Fig. 1S). The presence of a rigid acetylene bond causes the only possible position of the linear part of the substituent in the plane of the anthraquinone nucleus in all new compounds. The lowest estimated binding energy was observed for compound $\mathbf{1 4}$ (Table 2) with compact branched aliphatic substituent. The nitrogen atom of the substituent is capable of shifting the electron density from the terminal carbon atoms, creating the possibility of a $\pi$-sigma interaction.

Table 2. Results of molecular docking of the new 1-hydroxyanthraquinone derivatives 


\begin{tabular}{|llll|}
\hline 1 & MM41 & -0.212 & -12.698 \\
\hline 2 & 14 & -0.326 & -8.153 \\
\hline 3 & 34 & -0.284 & -7.657 \\
\hline 5 & 18 & -0.243 & -7.528 \\
\hline 6 & 19 & -0.275 & -7.438 \\
\hline 7 & 30 & -0.218 & -6.969 \\
\hline 8 & 9 & -0.254 & -6.607 \\
\hline 9 & 24 & -0.191 & -6.492 \\
\hline 10 & 29 & -0.249 & -6.485 \\
\hline 11 & 28 & -0.239 & -6.466 \\
\hline 12 & 23 & -0.230 & -5.75 \\
\hline 13 & 20 & -0.228 & -5.707 \\
\hline 14 & 36 & -0.176 & -5.101 \\
\hline 15 & 6 & -0.178 & -4.989 \\
\hline 16 & 7 & -0.171 & -4.440 \\
\hline 17 & 12 & -0.151 & -4.067 \\
\hline 18 & $\mathbf{8}$ & -0.180 & -3.416 \\
\hline$[a]$ Value is not genuine binding energy but estimated docking score. & -0.126 & -3.274 \\
\hline
\end{tabular}

The anthraquinone nucleus of $\mathbf{1 4}$ can be more evenly located, interacting with all $\pi$-systems of guanines (Fig. 1, B). The methylpiperazine ring of compound 34, apparently, causes more significant conformational difficulties, causing a displacement of the anthraquinone nucleus, which in this case is able to interact only with two nitrogenous bases of the G-quadruplex (Fig. 1, C). The binding energies for G-quadruplex complexes of compound $\mathbf{9}(-6.492 \mathrm{kcal} / \mathrm{mol})$ was slightly higher than for other Sonogashira cross-coupling reaction products $(\mathbf{6}, \mathbf{7}, \mathbf{8}, \mathbf{1 2})$. In the case of compound $\mathbf{9}$, a more large and polar ethyl-2acetamidobenzoate substituent causes a pronounced displacement of the entire molecule away from the central symmetry axis of the G-quadruplex due to the formation of hydrogen bonds and electrostatic interactions with the phosphate group of the neighboring nucleotide. It becomes possible to form a hydrogen bond between the proton of the hydroxyl group of the anthraquinone nucleus and the ketogroup of the purine ring of one of the guanines (Fig. 1, D). Finally, the docking of compounds 14, 34, and 9 as well as for MM41 revealed a $\mathrm{K}+$ binding of the core.

\section{Conclusion}


In summary, we developed a convenient method for modification of anthraquinone derivatives that can be used for modification of polyfunctionalized anthraquinones. Using this scheme, a series of 1-ethynyl4-hydroxyanthraquinones and 1-(3-aminopropynyl)-4-hydroxy-anthraquinones were prepared for the first time. Their cytotoxicity was determined by MTT assays against the MCF-7, DU-145, SNB-19, U-87MG, and hTERT lung fibroblasts cell lines. Among all the compounds synthesized, N-substituted 1-(3-(amino)prop1-ynyl)-4-hydroxyanthraquinones 14, 19, 24, 28-30, 34 stood out for their high selective cytotoxicity on the cancer cell lines than the others. The cytotoxicity of compounds 14 and 18 with alkyl substituent in aminopropargyl side chain on MCF-7 line was comparable to those of standard drug Doxorubicin. The $\mathrm{GI}_{50}$ value for compounds $\mathbf{2 8 - 3 0}$ was similar to that of doxorubicin against glioblastoma cancer cells.

Compounds $\mathbf{3 4}$ and $\mathbf{3 6}$ shown selectivity towards SNB-19 cell lines and compounds $\mathbf{1 4}$ and $\mathbf{1 9}$

demonstrated selectivity to DU-145 cells. The results reported herein pave the way for the further access of new targeted intercalating agents. In addition, due to their simplicity and effectiveness, it is likely that the new transformation of anthraquinone core will find use in the development of compounds with the 1( $(N$-substituted)aminopropyn-1-yl)anthraquinones, that could be used as scaffolds toward accessing other libraries of bioactive compounds.

\section{Experimental}

\section{General chemistry}

NMR spectra were acquired on Bruker AV-300 $\left({ }^{1} \mathrm{H}: 300.13 \mathrm{MHz},{ }^{13} \mathrm{C}: 75.47 \mathrm{MHz}\right)$ or Bruker AV-400 $\left({ }^{1} \mathrm{H}\right.$ : $400.13 \mathrm{MHz},{ }^{13} \mathrm{C}: 100.78 \mathrm{MHz}$ ) (Bruker BioSpin $\mathrm{GmbH}$, Rheinstetten, Germany) spectrometer. Deuterochloroform $\left(\mathrm{CDCl}_{3}\right)$ was used as a solvent, with residual $\mathrm{CHCl}_{3}\left(\delta_{\mathrm{H}}=7.24 \mathrm{ppm}\right)$ or $\mathrm{CDCl}_{3}\left(\delta_{\mathrm{C}}=\right.$ $76.9 \mathrm{ppm}$ ) being employed as internal standards. NMR assignments were supported by using COSY, $\mathrm{HMBC}$, and HSQC spectra if appropriate. In the description of the ${ }^{1} \mathrm{H}$ and ${ }^{13} \mathrm{C}-\mathrm{NMR}$ spectra for all compounds the anthraquinone skeleton and substituent atoms numeration system given in structure 14 and 36 was used (Scheme 2). IR absorption spectra were obtained for neat thin films by using a Bruker Vector-22 spectrometer. UV spectra were obtained on an HP 8453 UV-Vis spectrometer (Hewlette-Packard, Waldbronn, Germany) in EtOH solutions $\left(10^{-4} \mathrm{~mol} / \mathrm{L}\right)$. The specific rotation values $[\mathrm{a}]_{D}$ were determined on a PolAAr 3005 polarimeter. High-resolution mass spectrometry (HRMS) data were recorded on a Thermo Scientific DFS mass spectrometer (evaporator temperature $180-220^{\circ} \mathrm{C}$, El ionization at $70 \mathrm{eV}$. Melting points were determined using termosystem Mettler Toledo FP900 (USA).

The reaction progress and the purity of the obtained compounds were monitored by TLC on Sorbfil UV254 plates $\left(\mathrm{CHCl}_{3}, \mathrm{CH}_{2} \mathrm{Cl}_{2}, \mathrm{CCl}_{4}, \mathrm{CHCl}_{3}\right.$ :EtOAc - 1:1; detection under UV light). Column chromatography was performed by using silica gel 60 (0.063-0.200 mm, Merck KGaA, Darmstadt, Germany). Formalin (30\% formaldehyde in aq. solution), $\mathrm{Cul}, \mathrm{CuCl}$, copper(II) acetate monohydrate, tetra- $n$-butylammonium fluoride trihydrate (TBAF), tetra- $n$-butylammonium bromide $\left(\mathrm{Bu}_{4} \mathrm{NBr}\right.$, TBAB), phenylacetylene 2 , 4(methoxyphenyl)acetylene 4, 4-(fluorophenyl)acetylene 5, (trimethylsilyl)acetylene 11, diethylamine 13, dinmanulnminn 15 diinonmanulaminn $1<$ dihutulnminn 17 pyrrolidine 21, 2-methylpyrrolidine 22, piperidine Loading [MathJax]/jax/output/CommonHTML/fonts/TeX/fontdata.js 
25, 4-methylpiperidine 26 , morpholine $31, N$-methylpiperazine 32 , and azocane 35 were purchased from Alfa Aesar.

1-Hydroxy-4-iodo-9,10-anthraquinone 1 [34] and ethyl-5-ethynyl-anthranilate 6 [50] were obtained according to published procedures. (-)-Anabasine [27, (2S)-3-(piperidin-2-yl)pyridine] was isolated by extraction from the aerial part of the plant Anabasis aphylla $L$., $[\mathrm{a}]_{\mathrm{D}}=-61.22(c=4.5, \mathrm{EtOH})$ [51]. The solvents ( $\mathrm{DMF}, \mathrm{PhCH}_{3}, \mathrm{CHCl}_{3}, \mathrm{CH}_{2} \mathrm{Cl}_{2}, 1,4$-dioxane), as well as $\mathrm{Et}_{3} \mathrm{~N}$ were purified according to standard methods. Purity of all compounds was checked by TLC.

\section{General procedures for substitution of the halogen atom in 1-hydroxy-4-iodoanthraquinone 1 with the residue of alkynes}

To a stirred solution of 1-hydroxy-4-iodoanthraquinone $1(100.0 \mathrm{mg}, 0.285 \mathrm{mmol})$ in DMF $(4.00 \mathrm{~mL})$ under argon flow was added arylacetylene (2-5) or (trimethylsilyl)acetylene (10) $(0.43 \mathrm{mmol}), \mathrm{Pd}\left(\mathrm{PPh}_{3}\right)_{2} \mathrm{Cl}_{2}$ (20.1 mg, $0.028 \mathrm{mmol})$, TBAB (180 mg, $0.057 \mathrm{mmol})$, Cul (3.0 mg, $0.014 \mathrm{mmol})$, and $\mathrm{Et}_{3} \mathrm{~N}(0.12 \mathrm{~mL}, 0.86$ $\mathrm{mmol})$. The reaction mixture was heated to $65^{\circ} \mathrm{C}$ under stirring for 1-3.5 h. The solvent was removed in vacuo and the residue was purified by column chromatography using chloroform (for 6,7$)$ or dichloromethane (for $\mathbf{8}, 9,11$ ) as eluting solvent. Synthesis of 1-ethynyl-4-hydroxyanthraquinone (12)

Conditions A. A stirred solution of (trimethylsilyl)alkynyl substituted anthraquinone (11) (100 mg, 0.31 $\mathrm{mmol})$ in dichloromethane $(5 \mathrm{~mL})$, was treated with a solution of tetrabutyl ammonium fluoride $(0.163$ $\mathrm{mg}, 0.62 \mathrm{mmol})$ in dichloromethane $(5 \mathrm{~mL})$ and the mixture was stirred at $20^{\circ} \mathrm{C}$ for $30 \mathrm{~min}$. After completion based on TLC, the solvent was removed in vacuo. The solvent was removed under reduced pressure, and the residue was subjected to column chromatography $\left(\mathrm{CCl}_{4}\right)$ to give $57 \mathrm{mg}$ (yield $74 \%$ of compound (12) as an orange powder.

\section{General procedure for the synthesis ofN-substituted 1-(3-aminoprop-1-ynyl)-4-hydroxyanthraquinones (14, $18-20,23,24,28-30,33,34,36$ )}

Conditions a. Synthesis of compound (14). A stirred mixture of 1-ethynyl-4-hydroxyanthraquinone (12) (100 mg, $0.4 \mathrm{mmol})$, paraformaldehyde (36 mg, $1.2 \mathrm{mmol}$ ), diethylamine (13) (88 mg, $1.2 \mathrm{mmol})$, copper chloride $(1 \mathrm{mg}, 0.008 \mathrm{mmol})$ in dioxane $(10 \mathrm{~mL})$ was heated to $65^{\circ} \mathrm{C}$ for $1.5 \mathrm{~h}$ under argon. After the consumption of the starting materials, the solvent was removed under reduced pressure, and the crude material was purified via flash column chromatography (chloroform) to isolate $50 \mathrm{mg}$ (yield $39 \%$ ) of compound (14).

Conditions $b$. Synthesis of compound (14). A stirred mixture of 1-ethynyl-4-hydroxyanthraquinone (12) (100 mg, $0.4 \mathrm{mmol}$ ), paraformaldehyde (36 mg, $1.2 \mathrm{mmol}$ ), diethylamine (13) (88 mg, $1.2 \mathrm{mmol})$, copper iodide $(1.5 \mathrm{mg}, 0.008 \mathrm{mmol})$ in dioxane $(10 \mathrm{~mL})$ was heated to $65^{\circ} \mathrm{C}$ for $30 \mathrm{~min}$ under argon. The solvent was removed under reduced pressure, and the crude material was purified via flash column chromatography (chloroform) to isolate $64 \mathrm{mg}$ (yield 50\%) of compound (14). 
Conditions $c$. Synthesis of compound (14). A stirred mixture of 1-ethynyl-4-hydroxyanthraquinone (12) (100 mg, $0.4 \mathrm{mmol})$, paraformaldehyde (36 mg, $1.2 \mathrm{mmol})$, diethylamine (13) (88 mg, $1.2 \mathrm{mmol})$, $\mathrm{Cu}(\mathrm{OAc})_{2} \times \mathrm{H}_{2} \mathrm{O}(4 \mathrm{mg}, 0.02 \mathrm{mmol})$ in dioxane $(10 \mathrm{~mL})$ was heated to $65^{\circ} \mathrm{C}$ for 30 min under argon. The solvent was removed under reduced pressure, and the crude material was purified via flash column chromatography (chloroform) to isolate $74 \mathrm{mg} \mathrm{(57 \% )} \mathrm{of} \mathrm{compound} \mathrm{(14).}$

Conditions $d$. Secondary amine $(13,15-17,21,22,25-27,31,32,35)(2 \mathrm{mmol})$, formalin (60 mg, 2 $\mathrm{mmol}$ ), and $\mathrm{Cu}(\mathrm{OAc})_{2} \times \mathrm{H}_{2} \mathrm{O}(4 \mathrm{mg}, 0.02 \mathrm{mmol})$ were successive added in argon to the solution of 1ethynyl-4-hydroxyanthraquinone (12) $(100 \mathrm{mg}, 0.4 \mathrm{mmol})$ in dioxane $(10 \mathrm{~mL})$ and the reaction mixture was stirred at $65-70^{\circ} \mathrm{C}$ for a period from $30 \mathrm{~min}$ to $5 \mathrm{~h}$ (TLC-control). After the consumption of the starting materials, the reaction mixture was cold, evaporated and subjected to column chromatography (eluted with chloroform-ethylacetate).

\section{Synthesis of compound (14) from 1-hydroxy-4-(trimethylsilyl)ethynylanthraquinone (11). A stirred} solution of compound (11) $(130 \mathrm{mg}, 0.4 \mathrm{mmol})$ in dioxane $(10 \mathrm{~mL})$ was successive treated with tetra- $n$ butyl ammonium fluoride $(0.209 \mathrm{mg}, 0.8 \mathrm{mmol})$, formalin $(60 \mathrm{mg}, 2 \mathrm{mmol})$, diethylamine 13 (146 mg, 2 $\mathrm{mmol})$, and $\mathrm{Cu}(\mathrm{OAc})_{2} \times \mathrm{H}_{2} \mathrm{O}(4 \mathrm{mg}, 0.02 \mathrm{mmol})$ in an argon flow. The reaction mixture was stirred $30 \mathrm{~min}$ at room temperature and then heated to $65^{\circ} \mathrm{C}$ for $2 \mathrm{~h}$ and evaporated. Compound 14 was isolated in the yield $23 \%$ (eluted with chloroform).

1-Hydroxy-4-(phenylethynyl)anthracene-9,10-dione (6). Orange powder. Yield 72\%; m.p.: $304.7^{\circ} \mathrm{C}$ (decomp..); IR (KBr) v: 3420, $3400(\mathrm{OH}), 2197$ (C三C), 1664 (C=0), 1637 (C=0), 1592, 1490, 1460, 871, 798, 745, 727, 686 (C=C, CH-Ar) cm ${ }^{-1}$; UV (EtOH) $\lambda_{\max }(\lg \varepsilon): 258$ (4.25), 325 (3.79), 460 (3.49) nm; ${ }^{1} \mathrm{H}$ NMR $\left(\mathrm{CDCl}_{3}, 400 \mathrm{MHz}\right): \delta=7.27(\mathrm{~d}, 1 \mathrm{H}, J=8.9 \mathrm{~Hz}, \mathrm{H}-2), 7.32-7.42(\mathrm{~m}, 3 \mathrm{H}, \mathrm{H}-3 \varangle, 4 \rrbracket, 5 \rrbracket), 7.68(\mathrm{~m}, 2 \mathrm{H}, \mathrm{H}-2 \rrbracket, 6 \rrbracket)$, 7.62-7.87 (m, 3H, H-3,6,7), 8.29 (br d, 1H, J= 8.2 Hz, H-5), 8.34 (br d, 1H, J=8.2 Hz, H-8), $13.33(\mathrm{~s}, 1 \mathrm{H}, \mathrm{OH})$ ppm; $\left.{ }^{13} \mathrm{C} \mathrm{NMR} \mathrm{(} \mathrm{CDCl}_{3}, 75 \mathrm{MHz}\right): \delta=89.1$ (C-12), 94.0 (C-11), 115.4 (C-1区), 115.8 (C-9a), 122.9 (C-4), 123.6 (C-2), 126.2 (C-8), 127.3 (C-5), 128.0 (C-3区,5区), 128.2 (C-4区), 131.6 (C-2区,6区), 131.9 (C-10a), 132.7 (C-8a), 133.4 (C-6), 133.7 (C-4a), 134.5 (C-7), 142.5 (C-3), 162.7 (C-1), 180.7 (C-10), 188.1 (C-9) ppm; HRMS (ESI) $\mathrm{m} / \mathrm{z}$ calcd. for $\mathrm{C}_{22} \mathrm{H}_{12} \mathrm{O}_{3}, 324.0781$, found $324.0778[\mathrm{M}]^{+}$.

1-Hydroxy-4-((4-methoxyphenyl)ethynyl)anthracene-9,10-dione (7). Vinous powder. Yield 52\%; m.p.: 147.9

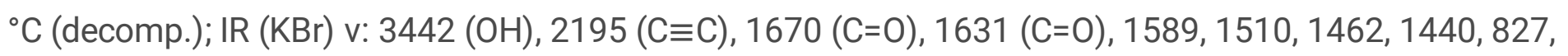
796, 727 (C=C, CH-Ar) cm ${ }^{-1}$; UV (EtOH) $\lambda_{\max }$ (lge): 255 (4.48), 269 (4.43), 339 (4.05), 483 (3.72) nm; ${ }^{1} \mathrm{H}$ $\operatorname{NMR}\left(\mathrm{CDCl}_{3}, 400 \mathrm{MHz}\right): \delta=3.83\left(\mathrm{~s}, 3 \mathrm{H}, 4 \rrbracket-\mathrm{OCH}_{3}\right), 6.90(\mathrm{~d}, 2 \mathrm{H}, J=8.5 \mathrm{~Hz}, \mathrm{H}-3 \rrbracket, 5 \rrbracket), 7.25(\mathrm{~d}, 1 \mathrm{H}, J=9.3 \mathrm{~Hz}$, $\mathrm{H}-2$ ), 7.63 (d, 2H, J=8.5 Hz, H-2囚,6囚), 7.73-7.86 (m, 3H, H-3,6,7), 8.28 (br d, 1H, J= 8.3 Hz, H-5), 8.34 (br d, $1 \mathrm{H}, J=8.3 \mathrm{~Hz}, \mathrm{H}-8), 13.34(\mathrm{~s}, 1 \mathrm{H}, \mathrm{OH}) \mathrm{ppm} ;{ }^{13} \mathrm{C} \mathrm{NMR}\left(\mathrm{CDCl}_{3}, 100 \mathrm{MHz}\right): \delta=55.2\left(\mathrm{OCH}_{3}\right), 88.5(\mathrm{C}-12), 94.8$ (C-11), 114.0 (C-3区,5区), 115.3 (C-1区), 116.0 (C-9a), 116.2 (C-4), 124.0 (C-2), 126.5 (C-8), 127.6 (C-5), 132.3 (C-10a), 132.5 (C-8a), 133.5 (C-2区,6区), 133.7 (C-6), 134.1 (C-4a), 134.8 (C-7), 142.7 (C-3), 159.9 (C-4区), 162.8 (C-1), 181.0 (C-10), 188.5 (C-9) ppm; HRMS (ESI) $\mathrm{m} / \mathrm{z}$ calcd. for $\mathrm{C}_{23} \mathrm{H}_{14} \mathrm{O}_{4}, 354.0887$, found 
1-Hydroxy-4-((4-fluorophenyl)ethynyl)anthracene-9,10-dione (8). Red powder. Yield 46\%; m.p.: $190.1^{\circ} \mathrm{C}$ (decomp.); IR (KBr) v: 3425 (OH), 2200 (C $\equiv \mathrm{C}), 1666$ (C=0), 1635 (C=0), 1593, 1508, 1462, 833, 794, 721,

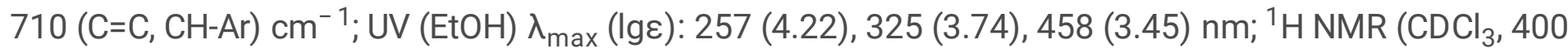
$\mathrm{MHz}): \delta=7.07(\mathrm{t}, 2 \mathrm{H}, J=8.6 \mathrm{~Hz}, \mathrm{H}-3 \rrbracket, 5 \rrbracket), 7.26(\mathrm{~d}, 1 \mathrm{H}, J=8.9 \mathrm{~Hz}, \mathrm{H}-2), 7.62-7.70(\mathrm{~m}, 2 \mathrm{H}, \mathrm{H}-2 \rrbracket, 6 \rrbracket), 7.74-$ $7.85(\mathrm{~m}, 3 \mathrm{H}, \mathrm{H}-3,6,7), 8.28(\mathrm{~d}, 1 \mathrm{H}, J=7.3 \mathrm{~Hz}, \mathrm{H}-5), 8.33(\mathrm{~d}, 1 \mathrm{H}, J=7.3 \mathrm{~Hz}, \mathrm{H}-8), 13.32(\mathrm{~s}, 1 \mathrm{H}, \mathrm{OH}) \mathrm{ppm} ;{ }^{13} \mathrm{C}$ $\operatorname{NMR}\left(\mathrm{CDCl}_{3}, 100 \mathrm{MHz}\right): \delta=89.1$ (C-12), $93.2(\mathrm{C}-11), 115.5$ (C-4), 115.6 (C-3囚,5区, $\left.\mathrm{J}_{\mathrm{C}-\mathrm{F}}=21.9 \mathrm{~Hz}\right), 116.1$ (C9a), $119.4\left(\mathrm{C}-1 \mathrm{X}, J_{\mathrm{C}-\mathrm{F}}=3.4 \mathrm{~Hz}\right), 124.0$ (C-2), 126.6 (C-8), 127.6 (C-5), 132.2 (C-10a), 133.0 (C-8a), 133.8 (C-

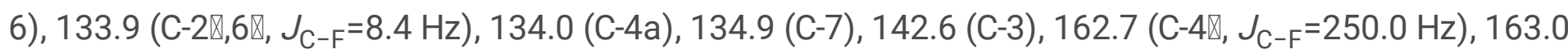
(C-1), 181.1 (C-10), 188.4 (C-9) ppm; HRMS (ESI) $\mathrm{m} / z$ calcd. for $\mathrm{C}_{22} \mathrm{H}_{11} \mathrm{FO}_{3}, 342.0687$, found $342.0693[\mathrm{M}]^{+}$.

Ethyl 2-acetylamino-5-((4-hydroxy-9,10-dioxo-9,10-dihydroanthracen-1-yl)ethynyl)benzoate \{ 4-(4acetylamino-3-ethoxycarbonylphenyl)ethynyl)-1-hydroxy- anthracene-9,10-dione\} (9). Orange powder. Yield 41\%; m.p.: $322.4^{\circ} \mathrm{C}$ (decomp.); IR (KBr) v. 3282, 3309 (NH, OH), $2198(\mathrm{C} \equiv \mathrm{C}), 1707$ (C=0), 1682 (C=0), 1662 (C=O), 1591, 1516, 1480, 1454, 850, 791, 775, 725 (C=C, CH-Ar) cm ${ }^{-1}$; UV (EtOH) $\lambda_{\max }(\mathrm{lg} \varepsilon)$ :

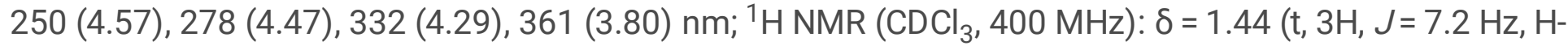
17), 2.25 (s, 3H, H-14), 4.41 (q, 2H, J= 7.2 Hz, H-16), $7.28(\mathrm{~d}, 1 \mathrm{H}, J=8.8 \mathrm{~Hz}, \mathrm{H}-2), 7.76-7.88(\mathrm{~m}, 4 \mathrm{H}, \mathrm{H}-$

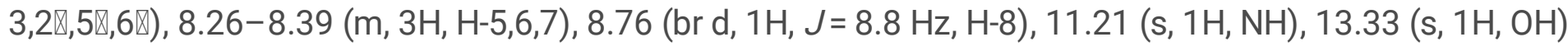
ppm; ${ }^{13} \mathrm{C} \mathrm{NMR}\left(\mathrm{CDCl}_{3}, 100 \mathrm{MHz}\right): \delta=14.1$ (C-17), 25.5 (C-14), 61.6 (C-16), 89.4 (C-12), 93.3 (C-11), 114.9 (C-3区), 115.5 (C-4), 116.1 (C-9a), 117.3 (C-1区), 120.2 (C-5区), 124.0 (C-2), 126.6 (C-8), 127.6 (C-5), 132.3 (C10a), 133.0 (C-8a), 133.8 (C-6), 134.0 (C-4a), 134.3 (C-6】), 134.9 (C-7), 137.8 (C-2ه), 141.6 (C-4囚), 142.8 (C3), 163.1 (C-1), 167.7 (C-15), 169.0 (C-13), 181.1 (C-10), 188.4 (C-9) ppm; HRMS (ESI) $\mathrm{m} / z$ calcd. for $\mathrm{C}_{27} \mathrm{H}_{19} \mathrm{NO}_{6}, 453.1207$, found $453.1210[\mathrm{M}]^{+}$.

1-Hydroxy-4-((trimethylsilyl)ethynyl)anthracene-9,10-dione (11). Brown powder. Yield 83\%; m.p.: 152.8-

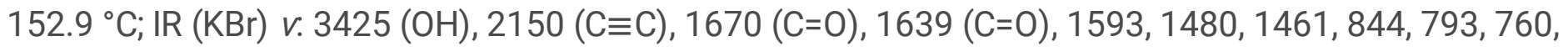
725, $704(\mathrm{C}=\mathrm{C}, \mathrm{CH}-\mathrm{Ar}) \mathrm{cm}^{-1} ;{ }^{1} \mathrm{H}$ NMR $\left(\mathrm{CDCl}_{3}, 400 \mathrm{MHz}\right): \delta=0.33\left(\mathrm{~s}, 9 \mathrm{H}, \mathrm{CH}_{3}\right), 7.22(\mathrm{~d}, 1 \mathrm{H}, J=8.9 \mathrm{~Hz}, \mathrm{H}-2)$, 7.73-7.84 (m, 3H, H-3,6,7), 8.26 (dd, $1 \mathrm{H}, J=8.7,1.8 \mathrm{~Hz}, \mathrm{H}-5), 8.33$ (dd, $1 \mathrm{H}, J=8.7,1.8 \mathrm{~Hz}, \mathrm{H}-8), 13.29$ (s, $1 \mathrm{H}$, $\mathrm{OH}) \mathrm{ppm} ;{ }^{13} \mathrm{C} \mathrm{NMR}\left(\mathrm{CDCl}_{3}, 150 \mathrm{MHz}\right): \delta=-0.2\left(3 \mathrm{CH}_{3}\right), 100.5(\mathrm{C}-12), 104.2(\mathrm{C}-11), 115.4(\mathrm{C}-4), 115.9$ (C9a), 123.7 (C-2), 126.5 (C-8), 127.7 (C-5), 132.2 (C-10a), 133.7 (C-6), 133.9 (C-8a), 134.8 (C-7), 143.6 (C-3), 163.1 (C-1), 180.8 (C-10), 188.5 (C-9) ppm; HRMS (ESI) $\mathrm{m} / z$ calcd. for $\mathrm{C}_{19} \mathrm{H}_{16} \mathrm{O}_{3} \mathrm{Si}, 320.0863$, found $320.0863[\mathrm{M}]^{+}$.

1-Ethynyl-4-hydroxyanthracene-9,10-dione (12). Orange powder. Yield 74\%; m.p.: $170.1^{\circ} \mathrm{C}$ (decomp.); IR

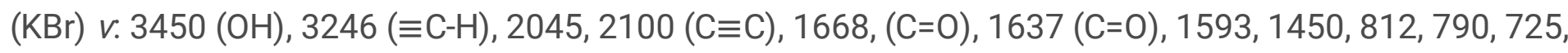
688 (C=C, CH-Ar) cm ${ }^{-1}$; UV (EtOH) $\lambda_{\max }(\mathrm{lg} \varepsilon): 255$ (4.48), 327 (3.33), 423 (3.77) nm; ${ }^{1} \mathrm{H} \mathrm{NMR}\left(\mathrm{CDCl}_{3}, 400\right.$ $\mathrm{MHz}): \delta=3.49(\mathrm{~s}, 1 \mathrm{H}, \equiv \mathrm{CH}), 7.23-7.27(\mathrm{~m}, 1 \mathrm{H}, \mathrm{H}-2), 7.76-7.85(\mathrm{~m}, 3 \mathrm{H}, \mathrm{H}-3,6,7), 8.28(\mathrm{dd}, 1 \mathrm{H}, J=8.6,1.8$ $\mathrm{Hz}, \mathrm{H}-5), 8.30$ (dd, J = 8.6, $2.2 \mathrm{~Hz}, 1 \mathrm{H}, \mathrm{H}-8), 13.24(\mathrm{~s}, 1 \mathrm{H}, \mathrm{OH}) \mathrm{ppm} ;{ }^{13} \mathrm{C} \mathrm{NMR}\left(\mathrm{CDCl}_{3}, 75 \mathrm{MHz}\right): \delta=81.8(\mathrm{C}-$ Loading [MathJax]/jax/output/CommonHTML/fonts/TeX/fontdata.js j.3 (C-8), 127.3 (C-5), 131.9 (C-10a), 133.5 (C- 
8a), 133.6 (C-6), 133.8 (C-4a), 134.6 (C-7), 143.2 (C-3), 162.9 (C-1), 180.8 (C-10), 188.0 (C-9) ppm; HRMS (ESI) $\mathrm{m} / \mathrm{z}$ calcd. for $\mathrm{C}_{16} \mathrm{H}_{8} \mathrm{O}_{3}, 248.0468$, found $248.0471[\mathrm{M}]^{+}$.

1-(3-(Diethylamino)prop-1-ynyl)-4-hydroxyanthracene-9,10-dione (14). Vinous powder. Yield 73\%; m.p.: $110.8^{\circ} \mathrm{C}$ (decomp.); IR (KBr) v. 3435 (OH), 2924 (C-H), 2195, 2200 (C三C), 1670 (C=0), 1639 (C=0), 1591, 1510, 1480, 1466, 840, 795, 691 (C=C, CH-Ar) cm ${ }^{-1}$; UV (EtOH) $\lambda_{\max }(\lg \varepsilon): 254$ (4.44), 442 (3.73) nm; ${ }^{1} \mathrm{H}$ $\operatorname{NMR}\left(\mathrm{CDCl}_{3}, 400 \mathrm{MHz}\right): \delta=1.16\left(\mathrm{t}, 6 \mathrm{H}, J=7.2 \mathrm{~Hz}, 2 \times \mathrm{CH}_{3}\right), 2.74\left(\mathrm{q}, 4 \mathrm{H}, J=7.2 \mathrm{~Hz}, 2 \times \mathrm{CH}_{2}\right), 3.79(\mathrm{~s}, 2 \mathrm{H}, \mathrm{H}-$ 13), $7.22(\mathrm{~d}, 1 \mathrm{H}, J=8.8 \mathrm{~Hz}, \mathrm{H}-2), 7.73(\mathrm{~d}, 1 \mathrm{H}, J=8.8 \mathrm{~Hz}, \mathrm{H}-3), 7.74-7.83(\mathrm{~m}, 2 \mathrm{H}, \mathrm{H}-6,7), 8.27(\mathrm{dd}, 1 \mathrm{H}, J=$ 8.6, 2.0 Hz, H-5), 8.31 (dd, $J=8.6,2.1 \mathrm{~Hz}, 1 \mathrm{H}, \mathrm{H}-8), 13.25$ (br s, $1 \mathrm{H}, \mathrm{OH}) \mathrm{ppm} ;{ }^{13} \mathrm{C} \mathrm{NMR}\left(\mathrm{CDCl}_{3}, 100 \mathrm{MHz}\right)$ : $\delta=12.6$ (C-16,16区), 41.9 (C-13), 47.4 (C-15,15区), 84.6 (C-11), 90.6 (C-12), 115.8 (C-4), 115.9 (C-9a), 123.9 (C-2), 126.5 (C-8), 127.6 (C-5), 132.2 (C-10a), 133.1 (C-8a), 133.7 (C-6), 134.0 (C-4a), 134.8 (C-7), 143.3 (C3), 162.8 (C-1), 181.0 (C-10), 188.4 (C-9) ppm; HRMS (ESI) $\mathrm{m} / z$ calcd. for $\mathrm{C}_{21} \mathrm{H}_{19} \mathrm{NO}_{3}, 333.1360$, found $333.1357[\mathrm{M}]^{+}$.

1-(3-(Dipropylamino)prop-1-ynyl)-4-hydroxyanthracene-9,10-dione (18). Brown powder. Yield 70\%; m.p.:

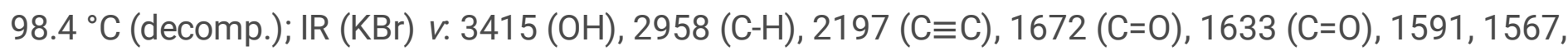
1464, 829, 808, 792, 721 (C=C, CH-Ar) cm ${ }^{-1}$; UV (EtOH) $\lambda_{\max }(\mathrm{lg} \varepsilon): 255$ (4.28), 434 (3.78) nm; ${ }^{1} \mathrm{H} \mathrm{NMR}$ $\left(\mathrm{CDCl}_{3}, 400 \mathrm{MHz}\right): \delta=0.94(\mathrm{t}, 6 \mathrm{H}, J=7.4 \mathrm{~Hz}, \mathrm{H}-17,17 \mathrm{X}), 1.58(\mathrm{~m}, 4 \mathrm{H}, \mathrm{H}-16,16 \mathrm{Q}), 2.63(\mathrm{t}, 4 \mathrm{H}, J=7.3 \mathrm{~Hz}, \mathrm{H}-$ 15,15区), 3.78 (s, 2H, H-13), 7.21-7.25 (m, 1H, H-2), 7.73 (d, 1H, J= 8.9 Hz, H-3), 7.76-7.85 (m, 2H, H-6,7), 8.27 (dd, $1 \mathrm{H}, J=8.5,2.0 \mathrm{~Hz}, \mathrm{H}-5), 8.29$ (dd, $J=8.5,2.0 \mathrm{~Hz}, 1 \mathrm{H}, \mathrm{H}-8), 13.27$ (br s, $1 \mathrm{H}, \mathrm{OH}) \mathrm{ppm} ;{ }^{13} \mathrm{C} \mathrm{NMR}$ $\left(\mathrm{CDCl}_{3}, 75 \mathrm{MHz}\right): \delta=11.9$ (C-17,17区), 20.6 (C-16,16区), 43.1 (C-13), 55.9 (C-15,15区), 84.7 (C-11), 90.8 (C-12), 115.8 (C-4), 116.0 (C-9a), 123.9 (C-2), 126.5 (C-8), 127.5 (C-5), 132.3 (C-10a), 133.1 (C-8a), 133.7 (C-6), 134.0 (C-4a), 134.8 (C-7), 143.3 (C-3), 162.8 (C-1), 181.0 (C-10), 188.4 (C-9) ppm; HRMS (ESI) m/z calcd. for $\mathrm{C}_{23} \mathrm{H}_{23} \mathrm{NO}_{3}, 361.1673$, found $361.1671[\mathrm{M}]^{+}$.

1-(3-(Diisopropylamino)prop-1-ynyl)-4-hydroxyanthracene-9,10-dione (19). Brown powder. Yield 77\%; m.p.: $95^{\circ} \mathrm{C}$ (decomp.); IR (KBr) v. 3421 (OH), 2966 (C-H), 2195, 2202 (C三C), 1670 (C=0), 1637 (C=0), 1595, 1512, 1462, 838, 802, 793, 725 (C=C) cm $\mathrm{cm}^{-1}$ UV (EtOH) $\lambda_{\max }$ (lge): 256 (4.05), 301 (3.94), 401 (3.83), 448 (3.72) nm; ${ }^{1} \mathrm{H} \mathrm{NMR}\left(\mathrm{CDCl}_{3}, 300 \mathrm{MHz}\right): \delta=1.19(\mathrm{~d}, 12 \mathrm{H}, J=6.6 \mathrm{~Hz}, \mathrm{H}-16,16 \bigotimes, 17,17 \rrbracket), 3.34$ (quintet, $2 \mathrm{H}, J=$ $6.6 \mathrm{~Hz}, \mathrm{H}-15,15 \mathrm{Z}), 3.81$ (s, 2H, H-13), 7,21 (d, 1H, J= 8.9 Hz, H-2), $7.70(\mathrm{~d}, 1 \mathrm{H}, J=8.9 \mathrm{~Hz}, \mathrm{H}-3), 7.75-7.85$ (m, 2H, H-6,7), 8.27 (dd, 1H, J= 8.6, 2.0 Hz, H-5), 8.31 (dd, J= 8.6, 2.1 Hz, 1H, H-8), 8.26 (dd, 1H, J= 8.6, 1.8 $\mathrm{Hz}, \mathrm{H}-5), 8.30$ (dd, $J=8.6,2.0 \mathrm{~Hz}, 1 \mathrm{H}, \mathrm{H}-8), 13.20$ (br s, $1 \mathrm{H}, \mathrm{OH}) \mathrm{ppm} ;{ }^{13} \mathrm{C} \mathrm{NMR}\left(\mathrm{CDCl}_{3}, 125 \mathrm{MHz}\right): \delta=20.5$ (C-16,17,16区,17区), 35.2 (C-15,15区), 48.5 (C-13), 83.0 (C-11), 95.1 (C-12), 115.9 (C-4), 116.2 (C-9a), 123.7 (C2), 126.4 (C-8), 127.4 (C-5), 132.2 (C-10a), 132.8 (C-8a), 133.5 (C-6), 134.0 (C-4a), 134.6 (C-7a), 142.9 (C3), 162.6 (C-1), 180.9 (C-10), 188.4 (C-9) ppm; HRMS (ESI) $m / z$ calcd. for $\mathrm{C}_{23} \mathrm{H}_{23} \mathrm{NO}_{3}, 361.1673$, found $361.1671[\mathrm{M}]^{+}$.

1-(3-(Dibutylamino)prop-1-ynyl)-4-hydroxyanthracene-9,10-dione (20). Brown powder. Yield 77\%; m.p.:

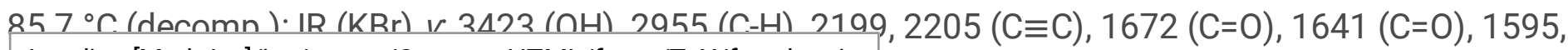
Loading [MathJax]/jax/output/CommonHTML/fonts/TeX/fontdata.js 
1525, 1466, 805, 787, 725 (C=C, CH-Ar) cm ${ }^{-1}$; UV (EtOH) $\lambda_{\max }$ (Ig $\left.\lg \right): 254$ (4.08), 440 (3.81) nm; ${ }^{1} \mathrm{H}$ NMR $\left(\mathrm{CDCl}_{3}, 400 \mathrm{MHz}\right): \delta=0.93(\mathrm{t}, 6 \mathrm{H}, J=7.2 \mathrm{~Hz}, \mathrm{H}-18,18 \mathrm{Q}), 1.31-1.42(\mathrm{~m}, 4 \mathrm{H}, \mathrm{H}-17,17 \mathrm{~d}), 1.47-1.58(\mathrm{~m}, 4 \mathrm{H}, \mathrm{H}-$ 16,16区), 2.63 (t, 4H, J=7.5 Hz, H-15,15区), $3.76(\mathrm{~s}, 2 \mathrm{H}, \mathrm{H}-13), 7.25$ (d, 1H, J= 8.9 Hz, H-2), $7.73(\mathrm{~d}, 1 \mathrm{H}, J=8.9$ $\mathrm{Hz}, \mathrm{H}-3), 7.76-7.84$ (m, 2H, H-6,7), 8.27 (dd, $1 \mathrm{H}, J=8.7,2.0 \mathrm{~Hz}, \mathrm{H}-5), 8.29$ (dd, J=8.7, $2.0 \mathrm{~Hz}, 1 \mathrm{H}, \mathrm{H}-8$ ), 13.25 (br s, 1H, OH) ppm; ${ }^{13} \mathrm{C}$ NMR (CDCl, $\left.125 \mathrm{MHz}\right): \delta=14.0$ (C-18,18区), 20.6 (C-17,17区), 29.7 (C-16,16区), 43.2 (C-13), 53.7 (C-15,15区), 84.5 (C-11), 91.3 (C-12), 116.0 (C-4), 116.0 (C-9a), 123.8 (C-2), 126.5 (C-8), 127.5 (C-5), 132.3 (C-10a), 133.1 (C-8a), 133.6 (C-6), 134.1 (C-4a), 134.7 (C-7), 143.3 (C-3), 162.7 (C-1), 180.9 (C-10), 188.4 (C-9) ppm; HRMS (ESI) $\mathrm{m} / z$ calcd. for $\mathrm{C}_{25} \mathrm{H}_{27} \mathrm{NO}_{3}, 389.1986$, found 389.1981[M] ${ }^{+}$.

1-Hydroxy-4-(3-(pyrrolidin-1-yl)prop-1-ynyl)anthracene-9,10-dione (23). Brown powder. Yield 51\%; m.p.: $129.2^{\circ} \mathrm{C}$ (decomp.); IR (KBr) v. 3427 (OH), 2926 (C-H), 2200 (CEC), 1668 (C=0), 1637 (C=0), 1594, 1558, 1462, 837, 790, 745, 729 (C=C, CH-Ar) cm ${ }^{-1}$; UV (EtOH) $\lambda_{\max }(\lg \varepsilon): 251$ (4.27), 402 (3.58), 433 (3.55) nm; ${ }^{1} \mathrm{H} \mathrm{NMR}\left(\mathrm{CDCl}_{3}, 400 \mathrm{MHz}\right): \delta=1.97(\mathrm{~m}, 4 \mathrm{H}, \mathrm{H}-16,17), 2.95(\mathrm{~m}, 4 \mathrm{H}, \mathrm{H}-15,18), 3.86(\mathrm{~s}, 2 \mathrm{H}, \mathrm{H}-13), 7.23(\mathrm{~d}, 1 \mathrm{H}$, $J=8.8 \mathrm{~Hz}, \mathrm{H}-2), 7.74(\mathrm{~d}, 1 \mathrm{H}, J=8.8 \mathrm{~Hz}, \mathrm{H}-3), 7.77-7.84(\mathrm{~m}, 2 \mathrm{H}, \mathrm{H}-6,7), 8.26$ (dd, $1 \mathrm{H}, J=8.7,2.0 \mathrm{~Hz}, \mathrm{H}-5)$,

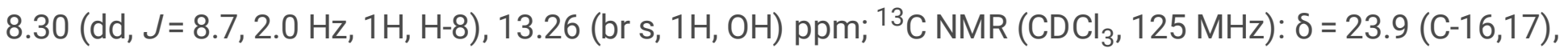
44.0 (C-13), 52.4 (C-15,18), 84.8 (C-11), 89.5 (C-12), 115.4 (C-4), 116.0 (C-9a), 123.9 (C-2), 126.6 (C-8), 127.6 (C-5), 132.3 (C-10a), 133.3 (C-8a), 133.8 (C-6), 134.0 (C-4a), 134.8 (C-7), 143.1 (C-3), 163.0 (C-1), 181.0 (C-10), 188.4 (C-9) ppm; HRMS (ESI) $\mathrm{m} / \mathrm{z}$ calcd for $\mathrm{C}_{21} \mathrm{H}_{17} \mathrm{NO}_{3}, 331.1203$, found 331.1198 [M] .

1-Hydroxy-4-(3-(2-methylpyrrolidin-1-yl)prop-1-ynyl)anthracene-9,10-dione (24). Brown powder. Yield 85\%; m.p. $94.2^{\circ} \mathrm{C}$ (decomp.); IR (KBr) v. 3420 (OH), 2924 (C-H), 2198 (CEC), 1670 (C=0), 1637 (C=0), 1592, 1520, 1481, 1462, 839, 829, 790, 727 (C=C, CH-Ar) cm ${ }^{-1}$; UV (EtOH) $\lambda_{\max }(\lg \varepsilon): 252$ (4.12), 403 (3.73), 433 (3.71) nm; ${ }^{1} \mathrm{H} \mathrm{NMR}\left(\mathrm{CDCl}_{3}, 400 \mathrm{MHz}\right): \delta=1.17$ (d, 3H, J=6.5 Hz, H-19), 1.42-1.54 (m, 1H, H-17), 1.701.91 (m, 2H, H-16), 1.95-2.06 (m, 1H, H-17), 2.70-2.82 (m, 2H, H-15,18), 3.17-3.25 (m, 1H, H-18), 3.72 and $3.92(\mathrm{AB}, \mathrm{d}, 2 \mathrm{H}, J=17.6 \mathrm{~Hz}, \mathrm{H}-13), 7.22(\mathrm{~d}, 1 \mathrm{H}, J=8.9 \mathrm{~Hz}, \mathrm{H}-2), 7.73(\mathrm{~d}, 1 \mathrm{H}, J=8.9 \mathrm{~Hz}, \mathrm{H}-3), 7.76-7.84$ (m, 2H, H-6,7), 8.27 (dd, 1H, J= 8.8, 2.0 Hz, H-5), 8.29 (dd, $J=8.8,1.8 \mathrm{~Hz}, 1 \mathrm{H}, \mathrm{H}-8), 13.26$ (br s, $1 \mathrm{H}, \mathrm{OH})$ ppm; ${ }^{13} \mathrm{C} \mathrm{NMR}\left(\mathrm{CDCl}_{3}, 125 \mathrm{MHz}\right): \delta=18.5$ (C-19), 21.5 (C-17), 32.7 (C-16), 41.4 (C-13), 52.9 (C-18), 57.0 (C15), 84.2 (C-11), 90.9 (C-12), 115.7 (C-4), 115.9 (C-9a), 123.7 (C-2), 126.4 (C-8), 127.5 (C-5), 132.2 (C-10a), 133.1 (C-8a), 133.6 (C-6), 134.0 (C-4a), 134.7 (C-7), 143.2 (C-3), 162.7 (C-1), 180.9 (C-10), 188.3 (C-9) ppm; HRMS (ESI) $\mathrm{m} / z$ calcd for $\mathrm{C}_{22} \mathrm{H}_{19} \mathrm{NO}_{3}, 345.1360$, found $345.1356[\mathrm{M}]^{+}$.

1-Hydroxy-4-(3-(piperidin-1-yl)prop-1-ynyl)anthracene-9,10-dione (28). Brown powder. Yield 49\%; m.p. $148.6^{\circ} \mathrm{C}$ (decomp.); IR (KBr) v. 3425 (OH), 2931 (C-H), 2197 (C $\left.\equiv \mathrm{C}\right), 1668$ (C=0), 1643 (C=0), 1593, 1518, 1462, 829, 808, 794, 724 (C=C, CH-Ar) cm ${ }^{-1}$; UV (EtOH) $\lambda_{\max }(\mathrm{lg} \varepsilon): 250$ (4.08), 440 (3.75) nm; ${ }^{1} \mathrm{H}$ NMR $\left(\mathrm{CDCl}_{3}, 300 \mathrm{MHz}\right): \delta=1.42-1.53(\mathrm{~m}, 2 \mathrm{H}, \mathrm{H}-17), 1.62-1.72(\mathrm{~m}, 4 \mathrm{H}, \mathrm{H}-16,18), 2.69$ (br s, 4H, H-15,19), 3.63 (s, 2H, H-13), 7.22 (d, $1 \mathrm{H}, J=8.9 \mathrm{~Hz}, \mathrm{H}-2), 7.73-7.84$ (m, 3H, H-3,6,7), 8.27 (dd, 1H, J=8.7, 2.2 Hz, H-5), 8.30 (dd, $J=8.7,2.0 \mathrm{~Hz}, 1 \mathrm{H}, \mathrm{H}-8), 13.27$ (br s, $1 \mathrm{H}, \mathrm{OH}) \mathrm{ppm} ;{ }^{13} \mathrm{C} \mathrm{NMR}\left(\mathrm{CDCl}_{3}, 100 \mathrm{MHz}\right): \delta=23.8(\mathrm{C}-17)$, 25.9 (C-16,18), 48.8 (C-13), 53.3 (C-15,19), 84.6 (C-11), 91.0 (C-12), 115.8 (C-4), 116.0 (C-9a), 122.9 (C-2), Loading [MathJax]/jax/output/CommonHTML/fonts/TeX/fontdata.js (C-6), 134.0 (C-4a), 134.8 (C-7), 143.2 (C-3), 
162.8 (C-1), 181.1 (C-10), 188.4 (C-9) ppm; HRMS (ESI) $\mathrm{m} / \mathrm{z}$ calcd. for $\mathrm{C}_{22} \mathrm{H}_{19} \mathrm{NO}_{3}, 345.1360$, found, $345.1356[\mathrm{M}]^{+}$.

1-Hydroxy-4-(3-(4-methylpiperidin-1-yl)prop-1-ynyl)anthracene-9,10-dione (29). Brown powder. Yield 41\%; m.p. $144.8^{\circ} \mathrm{C}$ (decomp.); IR (KBr) v. 3420 (OH), 2900 (C-H), 2197 (C三C), 1668 (C=0), 1643 (C=0), 1594, 1580, 1492, 1466, 810, 793, 756, 723 (C=C, CH-Ar) cm ${ }^{-1}$; UV (EtOH) $\lambda_{\max }(\lg \varepsilon): 250$ (3.98), 438 (3.73) nm; ${ }^{1} \mathrm{H} \mathrm{NMR}\left(\mathrm{CDCl}_{3}, 400 \mathrm{MHz}\right): \delta=0.94(\mathrm{~d}, 3 \mathrm{H}, J=6.6 \mathrm{~Hz}, \mathrm{H}-20), 1.29-1.38(\mathrm{~m}, 2 \mathrm{H}, \mathrm{H}-16,18), 1.38-1.46(\mathrm{~m}$, $1 \mathrm{H}, \mathrm{H}-17), 1.67-1.74$ (m, 2H, H-16,18), 2.32-2.41 (m, 2H, H-15,19), 3.00-3.07 (m, 2H, H-15,19), 3.64 (s, 2H, $\mathrm{H}-13), 7.22(\mathrm{~d}, 1 \mathrm{H}, J=8.8 \mathrm{~Hz}, \mathrm{H}-2), 7.74(\mathrm{~d}, 1 \mathrm{H}, J=8.8 \mathrm{~Hz}, \mathrm{H}-3), 7.76-7.83(\mathrm{~m}, 2 \mathrm{H}, \mathrm{H}-6,7), 8.27(\mathrm{dd}, 1 \mathrm{H}, J=$ 8.8, 2.0 Hz, H-5), 8.30 (dd, J=8.8, $2.0 \mathrm{~Hz}, 1 \mathrm{H}, \mathrm{H}-8), 13.27(\mathrm{~s}, 1 \mathrm{H}, \mathrm{OH}) \mathrm{ppm} ;{ }^{13} \mathrm{C} \mathrm{NMR}\left(\mathrm{CDCl}_{3}, 75 \mathrm{MHz}\right): \delta=$ 21.8 (C-20), 30.2 (C-17), 34.2 (C-16,18), 48.5 (C-13), 52.8 (C-15,19), 84.6 (C-11), 91.1 (C-12), 115.8 (C-4), 116.0 (C-9a), 123.9 (C-2), 126.5 (C-8), 127.6 (C-5), 132.3 (C-10a), 133.1 (C-8a), 133.7 (C-6), 134.0 (C-4a), 134.8 (C-7), 143.2 (C-3), 162.8 (C-1), 181.1 (C-10), 188.4 (C-9) ppm; HRMS (ESI) $\mathrm{m} / \mathrm{z}$ calcd. for $\mathrm{C}_{23} \mathrm{H}_{21} \mathrm{NO}_{3}$, 359.1516, found $359.1515[\mathrm{M}]^{+}$.

1-Hydroxy-4-(3-(2-(pyridin-3-yl)piperidin-1-yl)prop-1-ynyl)anthracene-9,10-dione (30). Dark orange powder. Yield 84\%; m.p. $160.4{ }^{\circ} \mathrm{C}$ (decomp.); $[\alpha]_{D}^{22}=0,788\left(c 0.5, \mathrm{CHCl}_{3}\right)$; IR (KBr) v. $3428(\mathrm{OH}), 2926(\mathrm{C}-\mathrm{H}), 2202$ $(\mathrm{C} \equiv \mathrm{C}), 1670$ (C=0), 1639 (C=0), 1593, 1578, 1479, 1462, 804, 790, 780, 723, 720 (C=C, CH-Ar) cm ${ }^{-1}$; UV (EtOH) $\lambda_{\max }(\mathrm{Ig} \varepsilon): 250$ (3.65), $442(3.76) \mathrm{nm} ;{ }^{1} \mathrm{H} \mathrm{NMR}\left(\mathrm{CDCl}_{3}, 500 \mathrm{MHz}\right): \delta=1.43-1.56(\mathrm{~m}, 1 \mathrm{H}, \mathrm{H}-16)$, 1.60-1.70 (m, 1H, H-16), 1.73-1.89 (m, 4H, H-17,18), 2.86-2.94 (m, 1H, H-19), 3.09-3.14 (m, 1H, H-19), 3.41 and $3.52(\mathrm{AB}, \mathrm{d} 2 \mathrm{H}, J=17.6 \mathrm{~Hz}, \mathrm{H}-13), 3.70-3.78(\mathrm{~m}, 1 \mathrm{H}, \mathrm{H}-15), 7.23(\mathrm{~d}, 1 \mathrm{H}, J=8.8 \mathrm{~Hz}, \mathrm{H}-2), 7.26-$ $7.31(\mathrm{~m}, 1 \mathrm{H}, \mathrm{H}-24), 7.72(\mathrm{~d}, 1 \mathrm{H}, J=8.8 \mathrm{~Hz}, \mathrm{H}-3), 7.75-7.88(\mathrm{~m}, 3 \mathrm{H}, \mathrm{H}-6,7,25), 8.28(\mathrm{dd}, 1 \mathrm{H}, J=8.6,1.8 \mathrm{~Hz}, \mathrm{H}-$ 5), 8.33 (dd, $1 \mathrm{H}, J=8.6,1.8 \mathrm{~Hz}, \mathrm{H}-8), 8.51$ (d, $1 \mathrm{H}, J=5.6 \mathrm{~Hz}, \mathrm{H}-23), 8.71(\mathrm{~d}, 1 \mathrm{H}, J=1.6 \mathrm{~Hz}, \mathrm{H}-21), 13.29$ (s, $1 \mathrm{H}, \mathrm{OH}) \mathrm{ppm} ;{ }^{13} \mathrm{C} \mathrm{NMR}\left(\mathrm{CDCl}_{3}, 125 \mathrm{MHz}\right): \delta=24.5$ (C-17), 25.8 (C-18), 35.5 (C-16), 45.2 (C-13), 53.0 (C-19), 62.7 (C-15), 85.5 (C-11), 90.0 (C-12), 115.6 (C-4), 115.9 (C-9a), 123.5 (C-2), 123.8 (C-24), 126.5 (C-8), 127.5 (C-5), 132.2 (C-10a), 133.1 (C-8a), 133.7 (C-6), 133.9 (C-4a), 134.8 (C-7), 135.2 (C-25), 139.1 (C-20), 143.2 (C-3), 148.5 (C-23), 149.4 (C-21), 162.8 (C-1), 180.9 (C-10), 188.4 (C-9) ppm; HRMS (ESI) $\mathrm{m} / \mathrm{z}$, calcd. for $\mathrm{C}_{27} \mathrm{H}_{22} \mathrm{~N}_{2} \mathrm{O}_{3}, 422.1625$, found $422.1623[\mathrm{M}]^{+}$.

1-Hydroxy-4-(3-morpholinoprop-1-ynyl)anthracene-9,10-dione (33). Brown powder. Yield 48\%; m.p. 172.8 ${ }^{\circ} \mathrm{C}$ (decomp.); IR (KBr) v. 3415 (OH), 2918 (C-H), 2197 (CEC), 1670 (C=0), 1641 (C=0), 1591, 1512, 1466, 858, 796, 725 (C=C, CH-Ar) cm ${ }^{-1}$; UV (EtOH) $\lambda_{\max }(\mathrm{lg} \varepsilon): 254$ (4.25), 436 (3.55) nm; ${ }^{1} \mathrm{H} \mathrm{NMR}\left(\mathrm{CDCl}_{3}, 400\right.$ $\mathrm{MHz}): \delta=2.71-2.82(\mathrm{~m}, 4 \mathrm{H}, \mathrm{H}-15,19), 3.65(\mathrm{~s}, 2 \mathrm{H}, \mathrm{H}-13), 3.80(\mathrm{t}, 4 \mathrm{H}, J=4.5 \mathrm{~Hz}, \mathrm{H}-16,18), 7.23(\mathrm{~d}, 1 \mathrm{H}, J=$ $8.8 \mathrm{~Hz}, \mathrm{H}-2), 7.73(\mathrm{~d}, 1 \mathrm{H}, J=8.8 \mathrm{~Hz}, \mathrm{H}-3), 7.77-7.84(\mathrm{~m}, 2 \mathrm{H}, \mathrm{H}-6,7), 8.27$ (dd, $1 \mathrm{H}, J=8.6,2.0 \mathrm{~Hz}, \mathrm{H}-5), 8.30$ (dd, $1 \mathrm{H}, J=8.6,1.8 \mathrm{~Hz}, \mathrm{H}-8), 8.27$ (dd, $1 \mathrm{H}, J=8.7,1.8 \mathrm{~Hz}, \mathrm{H}-5), 8.30$ (dd, $1 \mathrm{H}, J=8.7,2.0 \mathrm{~Hz}, \mathrm{H}-8), 13.27(\mathrm{~s}$, $1 \mathrm{H}, \mathrm{OH}) \mathrm{ppm} ;{ }^{13} \mathrm{C} \mathrm{NMR}\left(\mathrm{CDCl}_{3}, 100 \mathrm{MHz}\right): \delta=48.4$ (C-13), 52.4 (C-15,19), 66.9 (C-16,18), 85.0 (C-11), 89.9 (C-12), 115.4 (C-4), 116.0 (C-9a), 123.9 (C-2), 126.5 (C-8), 127.6 (C-5), 132.3 (C-10a), 133.2 (C-8a), 133.8 (C-6), 133.9 (C-4a), 134.8 (C-7), 143.1 (C-3), 162.9 (C-1), 181.1 (C-10), 188.4 (C-9) ppm; HRMS (ESI) m/z 
1-Hydroxy-4-(3-(4-methylpiperazin-1-yl)prop-1-ynyl)anthracene-9,10-dione (34). Brown powder solid. Yield

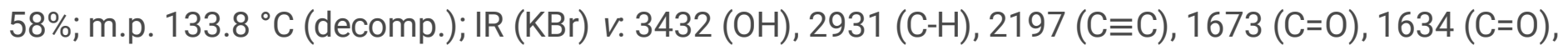
1593, 1510, 1464, 812, 796, 727 (C=C, CH-Ar) cm ${ }^{-1}$; UV (EtOH) $\lambda_{\max }(\lg \varepsilon): 255$ (4.07), 439 (3.74) nm; ${ }^{1} \mathrm{H}$ $\operatorname{NMR}\left(\mathrm{CDCl}_{3}, 400 \mathrm{MHz}\right): \delta=2.30$ (s, 3H, H-20), 2.41-2.63 (m,4H, H-16,18), 2.70-2.87 (m, 4H, H-15,19), $3.67(\mathrm{~s}, 2 \mathrm{H}, \mathrm{H}-13), 7.21(\mathrm{~d}, 1 \mathrm{H}, J=8.8 \mathrm{~Hz}, \mathrm{H}-2), 7.74(\mathrm{~d}, 1 \mathrm{H}, J=8.8 \mathrm{~Hz}, \mathrm{H}-3), 7.76-7.83(\mathrm{~m}, 2 \mathrm{H}, \mathrm{H}-6,7), 8.26$ (dd, $1 \mathrm{H}, J=8.8,2.0 \mathrm{~Hz}, \mathrm{H}-5), 8.29$ (dd, $1 \mathrm{H}, J=8.8,1.8 \mathrm{~Hz}, \mathrm{H}-8), 13.26(\mathrm{br} \mathrm{s}, 1 \mathrm{H}, \mathrm{OH}) \mathrm{ppm} ;{ }^{13} \mathrm{C} \mathrm{NMR}\left(\mathrm{CDCl}_{3}\right.$, $75 \mathrm{MHz}$ ): $\delta$ = 45.6 (C-20), 47.7 (C-13), 51.7 (C-15,19), 54.7 (C-16,18), 84.5 (C-11), 90.1 (C-12), 115.3 (C-4), 115.6 (C-9a), 123.5 (C-2), 126.2 (C-8), 127.3 (C-5), 131.9 (C-10a), 132.8 (C-8a), 133.4 (C-6), 133.6 (C-4a), 134.4 (C-7), 142.9 (C-3), 162.5 (C-1), 180.7 (C-10), 188.1 (C-9) ppm; HRMS (ESI) m/z calcd. for $\mathrm{C}_{22} \mathrm{H}_{20} \mathrm{O}_{3} \mathrm{~N}_{2}, 360.1468$, found $360.1474[\mathrm{M}]^{+}$.

1-(3-(Azocan-1-yl)prop-1-ynyl)-4-hydroxyanthracene-9,10-dione (36). Brown powder. Yield 70\%; m.p. 128.8 ${ }^{\circ} \mathrm{C}$ (decomp.); IR (KBr) v. 3425 (OH), 2197 (C $\left.\equiv \mathrm{C}\right), 1670$ (C=0), 1633 (C=0), 1591, 1572, 1511, 1480, 1462,

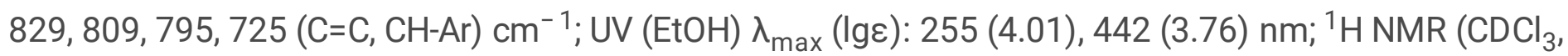
$300 \mathrm{MHz}): \delta=1.53-1.72(\mathrm{~m}, 10 \mathrm{H}, \mathrm{H}-16,17,18,19,20), 2.72-2.85$ (m, 4H, H-15,21), 3.71 (s, 2H, H-13), 7.22 $(\mathrm{d}, 1 \mathrm{H}, J=8.8 \mathrm{~Hz}, \mathrm{H}-2), 7.73(\mathrm{~d}, 1 \mathrm{H}, J=8.8 \mathrm{~Hz}, \mathrm{H}-3), 7.76-7.82(\mathrm{~m}, 2 \mathrm{H}, \mathrm{H}-6,7), 8.27$ (dd, $1 \mathrm{H}, J=8.8,2.0 \mathrm{~Hz}$,

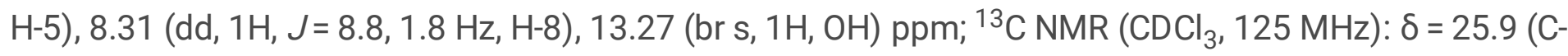
17,18,19), 48.9 (C-13), 53.3 (C-15,16,20,21), 81.6 (C-11), 91.3 (C-12), 114.1 (C-4), 114.3 (C-9a), 122.0 (C-2), 124.6 (C-8), 125.7 (C-5), 130.4 (C-10a), 131.1 (C-8a), 131.9 (C-6), 132.2 (C-4a), 132.9 (C-7), 141.6 (C-3), 160.9 (C-1), 179.2 (C-10), 186.6 (C-9) ppm; HRMS (ESI) $\mathrm{m} / z$ calcd. for $\mathrm{C}_{24} \mathrm{H}_{23} \mathrm{NO}_{3}, 373.1673$, found $373.1671[\mathrm{M}]^{+}$.

\section{MTT assay}

DMEM with $10 \%$ fetal bovine serum (Gibco, USA) was used for culturing. Cytotoxic activity of synthesized compounds $(6-9,14,18-20,23,24,28-30,33,34,36)$ was evaluated against four different tumor cells including breast carcinoma (MCF-7), human prostate cancer (DU-145, glioblastoma cancer (SNB19, and U-87 MG using MTT assay. The noncancer control was immortalized human fibroblasts (ATCC number CRL-4058). Cytotoxicity of the tested compounds was assessed using the MTT assay and the standard procedure [40]. Cells were inoculated into 96 -well plates (3,000 cells per well) and incubated at $37^{\circ} \mathrm{C}$ in $5 \%$ $\mathrm{CO} 2$ for attachment. Medium in wells was replaced after $24 \mathrm{~h}$ with fresh medium containing the tested compounds in DMSO (1\% v/v) and incubated for $72 \mathrm{~h}$. The cell viability was assessed through an MTT [3-(4,5-dimethylthiazol-2-yl)-2,5-phenyl-2H-tetrazolium bromide] conversion assay. $1 \%$ MTT was added to each well. Four hours later DMSO was added and mixed for $15 \mathrm{~min}$. Optical density $(D)$ of the samples was measured on a BioRad 680 multi-well spectrophotometer (USA) at the wavelength of $570 \mathrm{~nm}$. All compounds were tested at concentrations of $10,25,50$, and $100 \mu \mathrm{M}$ using the required controls, i.e., negative, DMSO (solvent), and positive, doxorubicin (standard cytostatic). Each experiment was performed independently in triplicate with three tests in each. Results were reported as mean inhibitory concentration $\mathrm{GI}_{50} \pm \mathrm{SEM}$. 


\section{Molecular modeling}

Molecular modeling was carried out in the CCDC Hermes 1.10.5 visualization environment using applications from the CSD Discovery 2020 package [52]. Three-dimensional structures of the derivatives were obtained empirically in the Conformer Generator [53] application. For the calculations, the XRD model of intramolecular human telomeric DNA G-quadruplex bound by the naphthalene diimide compound [54] with PDB ID 3UYH (resolution 1,95 Å) from Protein Data Bank was chosen. To model a possible mechanism of stabilization of G-quadruplex, molecular docking of new compounds was performed at the binding site of naphthalene diimide compound MM41 using GOLD [55]. The search area for docking was selected according to the size of MM41. Docking was performed in comparison with the MM41 molecule. The three-dimensional structure of MM41 were obtained in the PubChem database and prepared in the Conformer Generator application. Non-covalent interactions of compounds in the binding site were visualized using Biovia Discovery Studio Visualizer [56].

\section{Declarations}

Funding: This work was supported by Federal program AAAA-A21-121011490016-8 and by the Russian Foundation for Basic Research (project no. 19-53-44003). Authors would like to acknowledge the MultiAccess Chemical Research Center SB RAS for spectral and analytical measurements.

Acknowledgments: Authors would like to acknowledge the Multi-Access Chemical Research Center SB RAS for spectral and analytical measurements.

Conflicts of Interest: The authors declare that they have no conflict of interests.

\section{References}

1. Malik EM, Müller CE. Anthraquinones as pharmacological tools and drugs. Med Res Rev. 2016;36:705-48. https://doi.org/10.1002/med.21391

2. Srinivas G, Babykutty S, Sathiadevan PP, Srinivas P. Molecular mechanism of emodin action: transition from laxative ingredient to an antitumor agent. Med Res Rev. 2007;27:591-608. https://doi.org/10.1002/med.20095

3. Liu Y, Liang Y, Jiang J, Qin Q, Wang L, Liu X. Design, synthesis and biological evaluation of 1,4dihydroxyanthraquinone derivatives as anticancer agents. Bioorg Med Chem Lett. 2019;29:11201126. https://doi.org/10.1016/j.bmcl.2019.02.026

4. Eom T, Kim E, Kim J-S. In Vitro antioxidant, antiinflammation, and anticancer activities and anthraquinone content from Rumexcrispus root extract and fractions. Antioxidants. 2020;9:726 13. https://doi.org/10.3390/antiox9080726

5. Wei Y, Liu Q, Yu J, Feng Q, Zhao L, Song H, Wang W. Antibacterial mode of action of 1,8-dihydroxyanthraquinone from Porphyrahaitanensis against Staphylococcusaureus, Nat Prod Res. 
6. Chalothorn T, Rukachaisirikul V, Phongpaichit S, Pannara S, Tansakul C. Synthesis and antibacterial activity of emodin and its derivatives against methicillin-resistant Staphylococcusaureus.

Tetrahedron Lett. 2019;60:151004. https://doi.org/10.1016/j.tetlet.2019.151004

7. Shang X-F, Zhao Z-M, Li J-C, Yang G-Z, Liu Y-Q, Dai L-X, Zhang Z-J, Yang Z-G, Miao X-L, Yang C-J. Insecticidal and antifungal activities of Rheumpalmatum $\mathrm{L}$. anthraquinones and structurally related compounds. Ind Crops Prod. 2019;137:508-520. https://doi.org/10.1016/j.indcrop.2019.05.055

8. Wang W, Chen R, Luo Z, Wang Wei, Chen J. Antimicrobial activity and molecular docking studies of a novel anthraquinone from a marine-derived fungus Aspergillusversicolor, Nat. Prod Res. 2018;32:558-63. https://doi.org/10.1080/14786419.2017.1329732

9. Abdissa D, Geleta G, Bacha K, Abdissa N. Phytochemical investigation of Aloepulcherrima roots and evaluation for its antibacterial and antiplasmodial activities. PLoS ONE. 2017;12:1-10. https://doi.org/10.1371/journal.pone.0173882

10. Mohammed A, Ibrahim MA, Tajuddeen N, Aliyu AB, Isah MB. Antidiabetic potential of anthraquinones: A review. Phytother. Res. 2020;34:486-504.

11. Farsani FM, Vallian S, Ganjalikhany MR, Pourmoshir N. Characterization of novel non-synonymous genomic variants altering drug response of DNA topoisomerase II alpha. Int J Cancer Manag. 2019;12:e66993. doi: 10.5812/ijcm.66993

12. Liang X, WuQ, Luan S, Yin Z, He C, Yin L, ZouY, Yuan Z, LiL, SongX, He M, Lv Z, Zhang W. A comprehensive review of topoisomerase inhibitors as anticancer agents in the past decade. Eur $\mathrm{J}$ Med Chem. 2019;171:129-68. https://doi.org/10.1016/j.ejmech.2019.03.034

13. Gu L, Zhang H, Liu T, Draganov A, Yi S, Wang B, Zhou M. Inhibition of MDM2 by a rhein-derived compound AQ-101 suppresses cancer development in SCID mice. Molecular cancer therap. 2018;17:497-507. https://doi.org/10.1158/1535-7163.MCT-17-0566

14. Park H, Shim JS, Kim BS, Jung HJ, Huh T-L, Kwon HJ. Purpurin inhibits adipocyte-derived leucine aminopeptidase and angiogenesis in a zebrafish model. Biochem Biophys Res Commun. 2014;450:561-7. http://dx.doi.org/10.1016/j.bbrc.2014.06.017

15. He L, Bi JJ, Guo Q, Yu Y, Ye XF. Effects of emodin extracted from Chinese herbs on proliferation of non-small cell lung cancer and underlying mechanisms. Asian Pac. J. Cancer Prev. 2012;13:15051510. http://dx.doi.org/10.7314/APJCP.2012.13.4.1505

16. Koerner SK, Hanai J-I, Bai S, Jernigan FE, Oki M, Komaba C, Shuto E, Sukhatme VP, Sun L. Design and synthesis of emodin derivatives as novel inhibitors of ATP-citrate lyase. Eur J Med Chem. 2017;126:920-928. https://doi.org/10.1016/j.ejmech.2016.12.018

17. Pilžys T, Marcinkowski M, Kukwa W, Garbicz D, Dylewska M, Ferenc K, Mieczkowski A, Kukwa A, Migacz E, Wołosz D, Mielecki D, Klungland A, Piwowarski J, Poznański J, Grzesiuk E. ALKBH overexpression in head and neck cancer: potential target for novel anticancer therapy. Sci Rep.

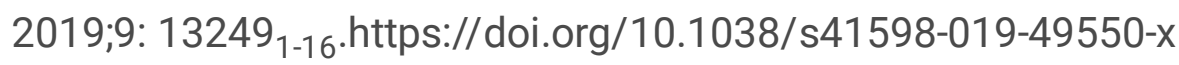

18. Orhan IE. Potential of natural products of herbal origin as monoamine oxidase inhibitors. Curr Pharm 
19. Lee HW, Ryu HW, Kang M-G, Park D, Oh S-R, Kim H. Selective inhibition of monoamine oxidase A by purpurin, an anthraquinone, Bioorg. Med. Chem. Lett. 2017;27: 1136-40.

https://doi.org/10.1016/j.bmcl.2017.01.085

20. Song Y, Lim J, Seo YH. A novel class of anthraquinone-based HDAC6 inhibitors. Eur J Med Chem. 2019;164:263-72. https://doi.org/10.1016/ j.ejmech.2018.12.056

21. Zuravka I, Sosic A, Gatto B, Göttlich, R. Synthesis and evaluation of a bis-3-chloropiperidine derivative incorporating an anthraquinone pharmacophore. Bioorg Med Chem Lett. 2015;25:4606-9. https://doi.org/10.1016/j.bmcl.2015.08.042

22. Zarren G, Shafiq N, Arshad U, Rafiq N, Parveen S, Ahmad Z. Copper-catalyzed one-pot relay synthesis of anthraquinone based pyrimidine derivative as a probe for antioxidant and antidiabetic activity. J. Molecular Structure. 2021;1227:129668 1 14. https://doi.org/10. 1016/j.molstruc.2020.129668

23. Sadeghi-Alaibadi H, Tabarzadi M, Zarghi A. Synthesis and cytotoxic evaluation of two novel anthraquinone derivatives. II. Farmaco. 2004;59:645-9. https://doi.org/:10.1016/j.farmac. 2004.03.006

24. Rafehi M, Malik EM, Neumann A, Abdelrahman A, Hanck T, NamasivayamV, Müller CE, Baqi Y. Development of potent and selective antagonists for the UTP-activated $\mathrm{P}_{2} \mathrm{Y}_{4}$ receptor. J Med Chem. 2017;60:3020-38. https://doi.org/10.1021/acs.jmedchem.7b00030

25. Baqi Y, Müller CE. Synthesis of alkyl- and aryl-aminosubstituted anthraquinone derivatives by microwave-assisted copper(0)-catalyzed Ullmann coupling reactions. Nat Protoc. 2010;5:945-953. https://doi.org/10.1038/nprot.2010.63

26. Baqi Y, Rashed M, Schäkel L, Malik EM, Pelletier J, Sévigny J, Fiene A, Müller CE. Development of Anthraquinone Derivatives as Ectonucleoside Triphosphate Diphosphohydrolase (NTPDase) Inhibitors With Selectivity for NTPDase2 and NTPDase3. Fronties Pharmacol.2020;11:1282. https://doi:org/10.3389/fphar.2020.01282

27. Pant PL, Sonune RK, Shankarling GS. Choline hydroxide promoted synthesis of N-aryl anthraquinone derivatives: Metal free approach to Ullmann coupling reactions. ChemistrySelect. 2018;3:5249-53. https://doi.org/10.1002/slct.201800546

28. Beletskaya IP, Averin AD, Bessmertnykh AG, Guilard R. Synthesis of diazacrown ethers based on anthracene and anthraquinone by $\mathrm{Pd}$-catalyzed amination reactions. Tetrahedron Lett. 2001;42:4987-9. https://doi.org/10.1016/S0040-4039(01)00832-2

29. Shaikh AM, Chacko S, Kamble RM. Synthesis, optoelectronic and theoretical investigation of anthraquinone amine-based donor-acceptor derivatives. ChemistrySelect. 2017;2:7620-9. https://doi.org/10.1002/slct.201701475

30. Sirazhetdinova NS, Savelyev VA, Frolova TS, Baev DS, Oleshko OS, Klimenko LS, Chernikov IV, Sarojan TA, Pokrovskii AG, Shults EE. 1-Hydroxyantraquinones containing aryl substituent as potent and selective anticancer agents. Molecules. 2020; 25:2547 $1-26$.

https://doi.org/10.3390/molecules25112547 
31. Lauder K, Toscani A, Scalacci N, Castagnolo D. Synthesis and Reactivity of Propargylamines in Organic Chemistry. Chem Rev. 2017;117:14091-14200.

32. Peshkov VA, Pereshivko OP, Van der Eycken EV. A walk around the $A^{3}$-coupling. Chem Soc Rev. 2012;41:3790-807. https://doi.org/10.1039/C2CS15356D

33. Volkova Y, Baranin S, Zavarzin I. A ${ }^{3}$ Coupling Reaction in the Synthesis of Heterocyclic Compounds. Adv Synth Catal. 2021;363:40-61. https://doi.org/10.1002/adsc.202000866

34. Galevskaya TP, Moroz AA, Myasnikova RN, Shvartsberg MS. lodination of hydroxyanthraquinones. Russ J Org Chem. 1988;24:358-62.

35. Bauman VT, Shul'ts EE, Kononchuk VV, Bagryanskaya IYu, Shakirov MM, Tolstikov GA. Synthetic Transformations of Isoquinoline Alkaloids. 1-Alkynyl-3,6-dimethoxy-N-methyl-4,5a-epoxy-6,18endoethenobenzo[]]isomorphinans and their transformations. Russ J Org Chem. 2013;49:1502-13. doi:10.1134/S1070428013100175

36. Jeffery T. On the efficiency of tetraalkylammonium salts in Heck type reactions Tetrahedron. 1996;52:10113-130. https://doi.org/10.1016/0040-4020(96)00547-9

37. Reetz MT, Westermann E. Phosphane-free palladium-catalyzed coupling reactions: The decisive role of Pd nanoparticles. Angew Chem Int Ed. 2000;39:165-8. https://doi.org/10.1002/(SICI)15213773(20000103)39:1<165:AID-ANIE165>3.0.C0;2-B

38. Thibault RJ, Takizawa K, Lowenheilm P, Helms B, Mynar JL, Frechet JM, Hawker CJ. A versatile new monomer family: Functionalized 4-vinyl-1,2,3-triazoles via click chemistry. J Am Chem Soc. 2006;128:12084-5. https://doi.org/10.1021/ja0648209

39. Beltrán E, Serrano JL, Sierra T, Giménez R. Tris(triazolyl)triazine via click-chemistry: A C3 electrondeficient core with liquid crystalline and luminescent properties. Org Lett. 2010;12:1404 -7. doi:10.1021/ol902900y

40. Wilson JK, Sargent JM, Elgie AW, Hill JG, Taylor CG. A feasibility study of the MTT assay for chemosensitivity testing in ovarian malignancy. Br J Cancer. 1990;62:189-94.

41. Koyama M, Takahashi K, Chou TC, Darzynkiewicz Z, Kapuscinski J, Kelly TR, Watanabe KA. Intercalating agents with covalent bond forming capability. A novel type of potential anticancer agents. Derivatives of chrysophanol and emodin. J Med Chem. 1989;32:1594-9.

42. Katzhendler J, Gean K-F, Barad G, Tashma Z, Ben-shoshan R, Ringel I, Bachrach U, Ramu A. Synthesis of aminoanthraquinone derivatives and their in vitro evaluation as potential anti-cancer drugsSynthèse de dérivés aminoanthraquinoniques et leur évaluation in vitro comme anti-tumoraux potentiels. Eur. J Med Chem. 1989;24:23-30. https://doi.org/10.1016/0223-5234(89)90159-1

43. Smith PJ, Blunt NJ, Desnoyers R, Giles Y, Patterson LH. DNA topoisomerase II-dependent cytotoxicity of alkylaminoanthraquinones and their N-oxides. Cancer Chemother Pharmacol. 1997;39:455-61. https://doi.org/10.1007/s002800050598

44. Huang H-S, Chin H-F, Yeh P-F, Yuan C-L. Structure-based design and synthesis of regioisomeric 
2004;87:999-1006.https://doi.org/10.1002/hlca.200490093

45. Pors K, Shnyder SD, Teesdale-Spittle PH, Hartley JA, Zloh M, Searcey M, Patterson LH. Synthesis of DNA-directed pyrrolidinyl and piperidinyl confined alkylating chloroalkylaminoanthraquinones: Potential for development of tumor-selective N-oxides. J Med Chem. 2006;49:7013-23. doi:10.1021/jm0608154

46. Wang W, Hu S, Gu Y, Yan Y, Stovall DB, Li D, Sui G. Human MYC G-quadruplex: From discovery to a cancer therapeutic target. Biochim Biophys Acta Rev Cancer. 2020;1874:188410. https://doi.org/10.1016/j.bbcan.2020.188410

47. Roy S, Ali A, Kamra M, Muniyappa K, Bhattacharya S. Specific stabilization of promoter GQuadruplex DNA by 2,6-disubstituted amidoanthracene-9,10-dione based dimeric distamycin analogues and their selective cancer cell cytotoxicity. Eur J Med Chem. 2020;195:112202. https://doi.org/1016/j.ejmech.2020.112202.

48. Shchekotikhin AE, Glazunova VA, Dezhenkova LG, Luzikov YN, Sinkevich YB, Kovalenko LV, Buyanov VN, Balzarini J, Huang FC, Lin JJ, Huang HS, Shtil AA, Preobrazhenskaya MN. Synthesis and cytotoxic properties of 4,11-bis[(aminoethyl)-amino]anthra[2,3-b]thiophene-5,10- diones, novel analogues of antitumor anthracene-9,10-diones. Bioorg Med Chem. 2009; 17:1861-9. https://doi.org/10.1016/j.bmc.2009.01.047

49. Ongaro A, Ribaudo G, Zagotto G, Memo M, Gianoncelli A. Synthesis via A3 Coupling Reaction of Anthracene-Propargylamine as a New Scaffold for the Interaction with DNA ChemistrySelect. 2019;4:13138-42. https://doi.org/10.1002/slct.201902975

50. Osadchii SA, Shults EE, Polukhina EV, Shakirov MM, Vasilevskii SF, Stepanov AA, Tolstikov GA. Study of alkaloids of the Siberian and Altai flora 13. Synthesis of alkynyllappaconitines. Russ Chem Bull Int Ed. 2007;56:356-60. https://doi.org/10.1007/s11172-007-0058-4

51. Osadchii SA, Shults EE, Polukhina EV, Shakirov MM, Vasilevskii SF, Stepanov AA, Tolstikov GA. Study of alkaloids of the Siberian and Altai flora 14 . Synthesis of alkaloid-based tertiary $N$-(3-arylprop-2ynyl)amines. Russ Chem Bull Int Ed. 2007;56:1261-7. https://doi.org/10.1007/s11172-007-0191-0

52. Groom CR, Bruno IJ, Lightfoot MP, Ward SC. The Cambridge structural database. Acta Crystallogr., Sect. B: Struct. Science, Crystal Eng. Mat. 2016;72:171-9. doi:10.1107/S2052520616003954

53. Taylor R, Cole J , Korb O, McCabe P. Knowledge-based libraries for predicting the geometric preferences of druglike molecules. Chem Inform Mod. 2014;54:2500-14. doi:10.1021/ci500358p

54. Micco M, Collie GW, Dale AG, Ohnmacht SA, Pazitna I, Gunaratnam M, Reszka AP, Neidle S. Structurebased design and evaluation of naphthalene diimide G-quadruplex ligands as telomere targeting agents in pancreatic cancer cells. J Med Chem. 2013;56(7):2959-74. doi:10.1021/jm301899y

55. Jones G, Willett P, Glen RC, Leach AR, Taylor R. Development and validation of a genetic algorithm for flexible docking. J Mol Biol. 1997;267:727-48. doi:10.1006/JMBI.1996.0897

56. Biovia DS, Berman HM, Westbrook J, Feng Z, Gilliland G, Bhat TN, Richmond TJ. Dassault Systèmes Dassault Systèmes, 2016. J Chem Phys. 


\section{Figures}
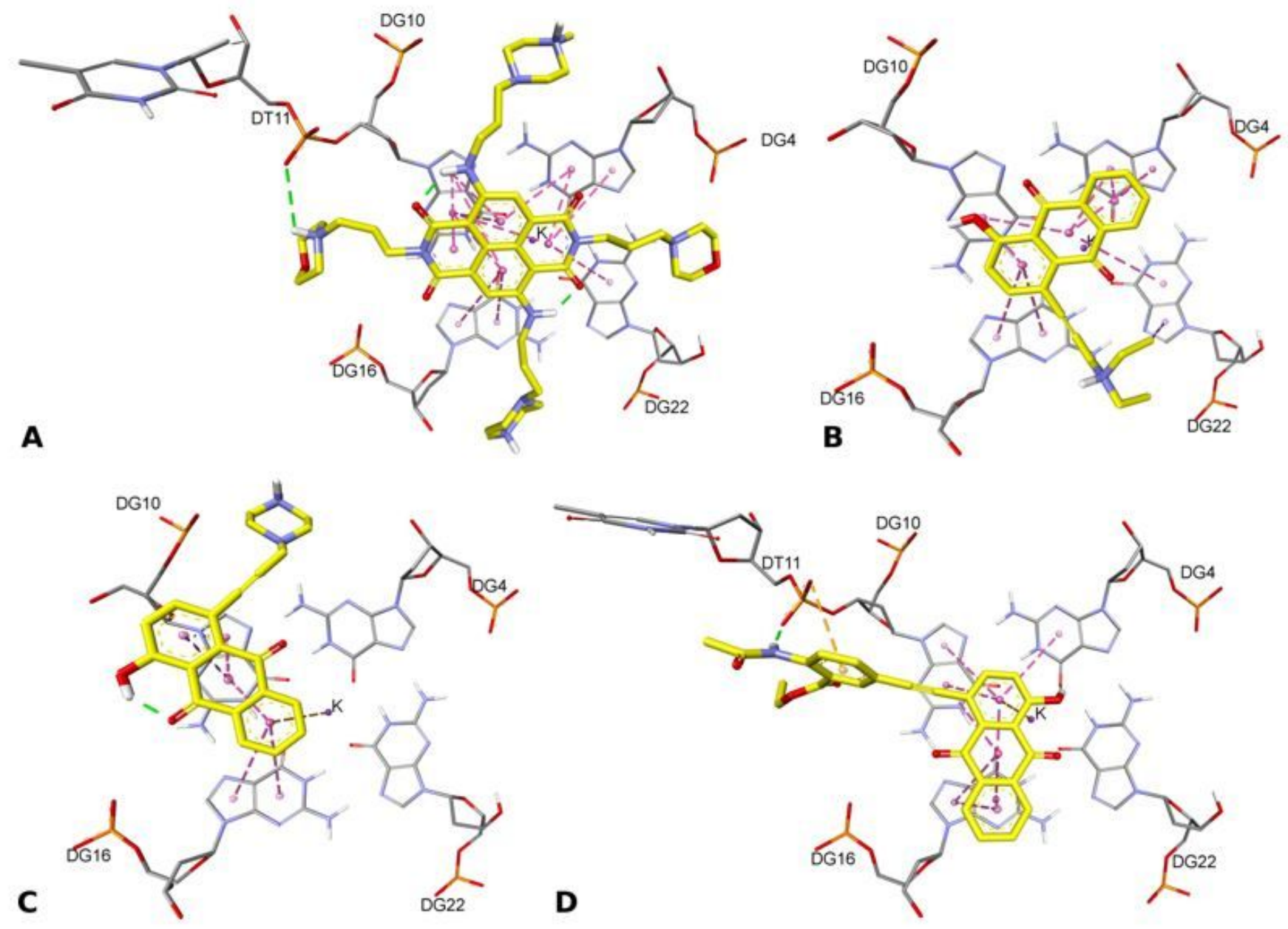

Figure 1

Docking of new compounds in G-quadruplex binding site. A - ligand MM41, B - compound 14, C compound 34, D - compound 9. Noncovalent interactions of molecules are shown by dotted lines: green hydrogen bonds, orange - electrostatic interactions, purple - stacking and $\pi$-sigma interactions. 


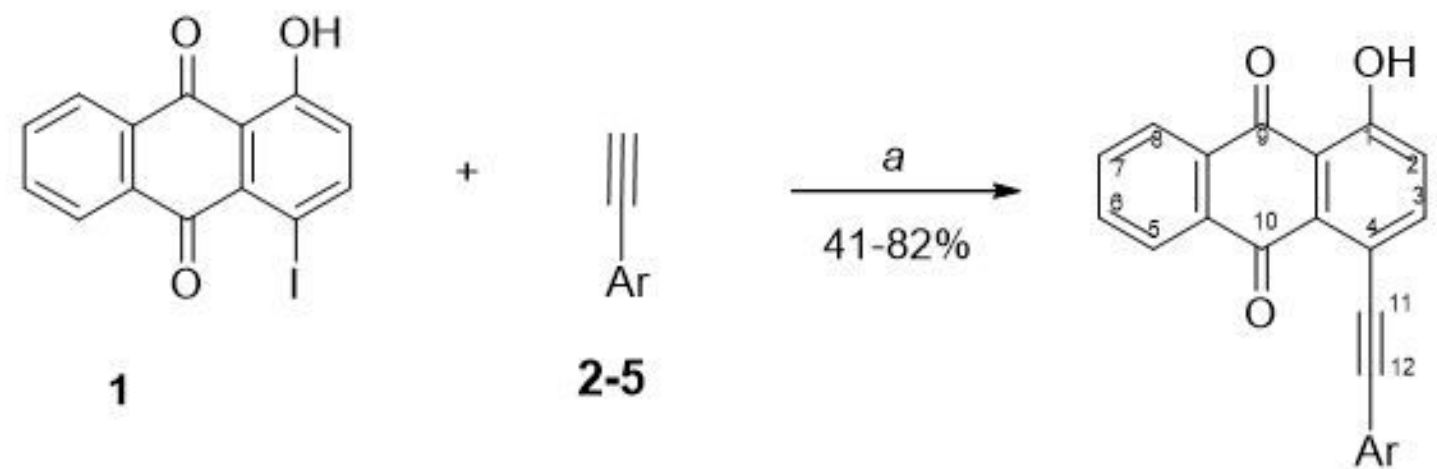

2, 6: $\mathrm{Ar}=\mathrm{Ph}$;

3, 7: $\mathrm{Ar}=4-\mathrm{OCH}_{3} \mathrm{C}_{6} \mathrm{H}_{4}$;

6- 9

4, 8: $\mathrm{Ar}=4-\mathrm{FC}_{6} \mathrm{H}_{4}$;

5, 9: $\mathrm{Ar}=4-\mathrm{NHAC}-3-\mathrm{C}(=\mathrm{O}) \mathrm{OEt}-\mathrm{C}_{6} \mathrm{H}_{3}$.

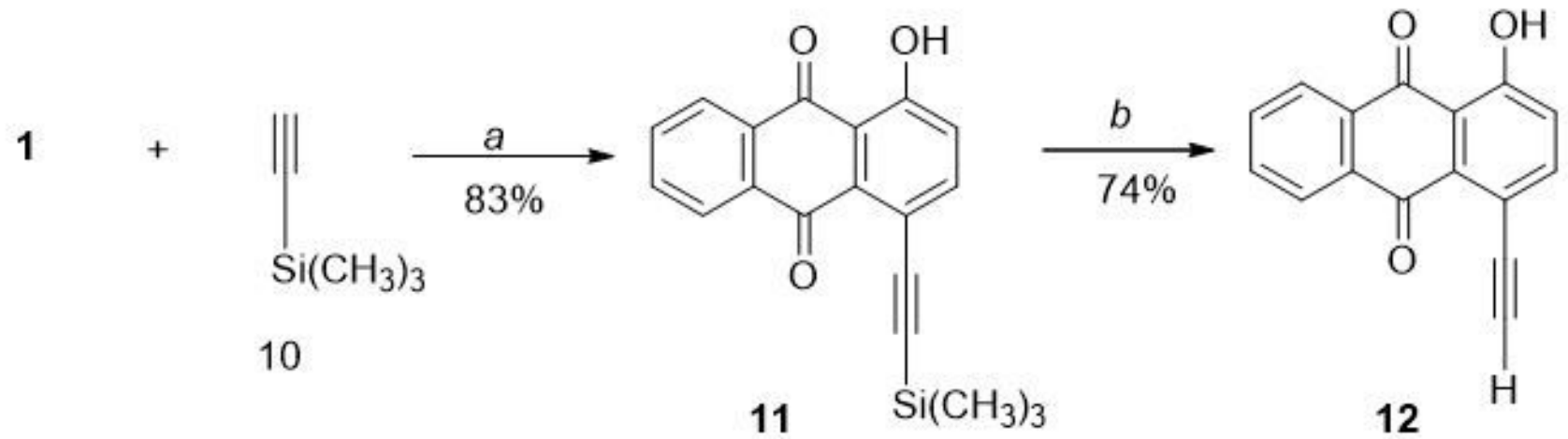

\section{Figure 2}

Synthesis of 1-alkynyl-4-hydroxyanthraquinones. Reagent and conditions: (a): $\mathrm{Pd}(\mathrm{Ph} 3) 2 \mathrm{Cl} 2, \mathrm{Cul}, \mathrm{Et} 3 \mathrm{~N}$, Bu4NBr, DMF, 65oC, 1h; (b): Bu4NF, CH2Cl2, rt, 30 min. 

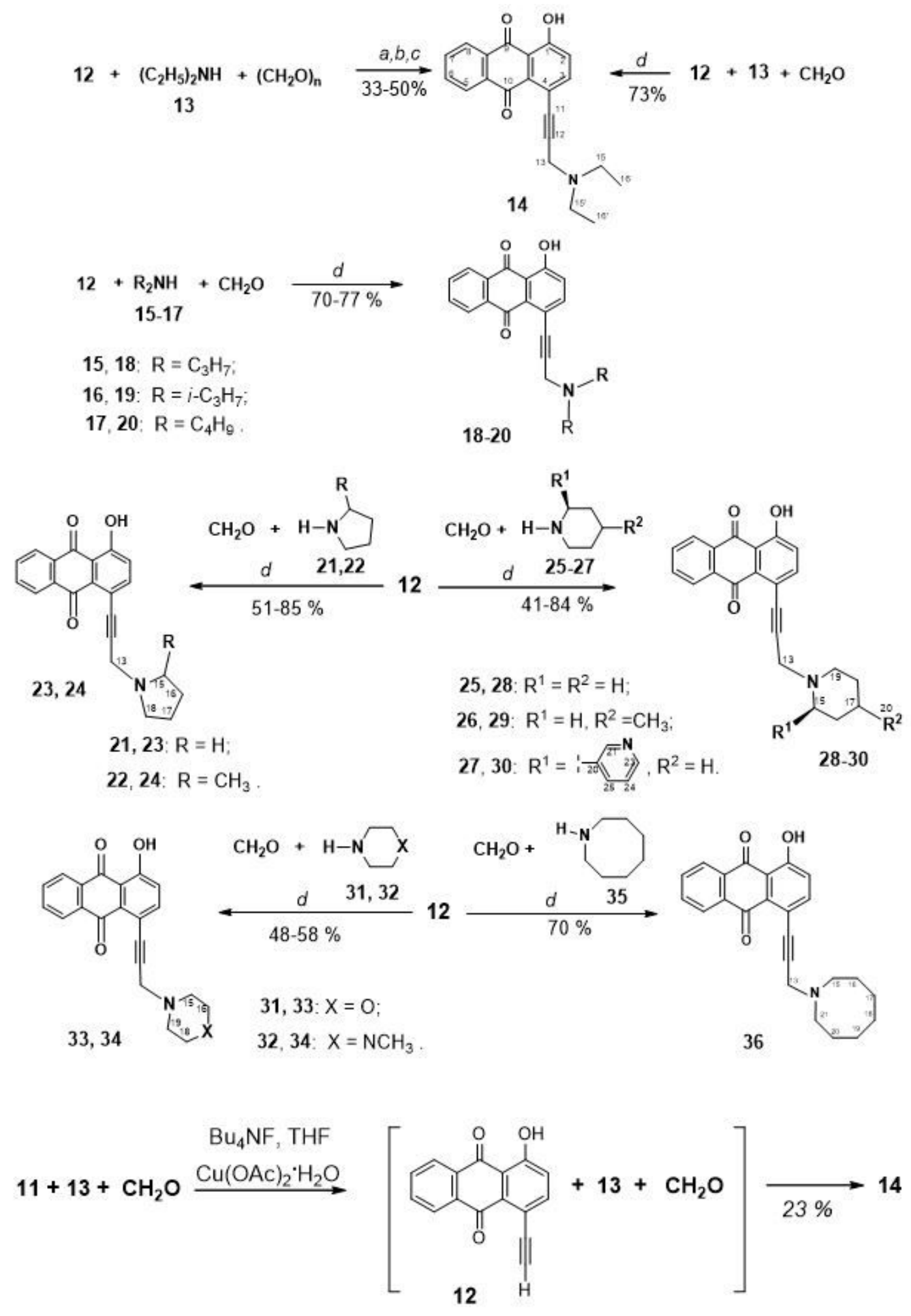

\section{Figure 3}

Synthesis of N-substituted 1-(3-(amino)prop-1-ynyl)-4-hydroxyanthracene-9,10-diones. Reagent and conditions: (a): Cul, dioxane, 65oC, $30 \mathrm{~min}$; (b): CuCl, dioxane, 65oC, $90 \mathrm{~min}$; (c): $\mathrm{Cu}(\mathrm{OAc}) 2 \times \mathrm{H} 20,650 \mathrm{C}$, dioxane, 2h; (d): $\mathrm{Cu}(\mathrm{OAc}) 2 \times \mathrm{H} 2 \mathrm{O}, 650 \mathrm{C}, 30 \mathrm{~min}-5 \mathrm{~h}$; (e) Bu4NF (2 equiv.), Cu(OAc)2×H2O, 30 min, rt, then $650 \mathrm{C}, 2 \mathrm{~h}$. 


\section{Supplementary Files}

This is a list of supplementary files associated with this preprint. Click to download.

- GraphicalAbstract.jpg 